\title{
Recent Trends of microRNA Significance in Pediatric Population Glioblastoma and Current Knowledge of Micro RNA Function in Glioblastoma Multiforme
}

\author{
Marek Mazurek ${ }^{1}$, Cezary Grochowski ${ }^{2, *}{ }^{\oplus}$, Jakub Litak ${ }^{3} \oplus$, Ida Osuchowska ${ }^{2}$, \\ Ryszard Maciejewski ${ }^{2}$ and Piotr Kamieniak ${ }^{1}$ \\ 1 Department of Neurosurgery and Pediatric Neurosurgery, Medical University of Lublin, Jaczewskiego 8, \\ 20-954 Lublin, Poland; marekmazurek@hotmail.com (M.M.); bea_43@o2.pl (P.K.) \\ 2 Department of Anatomy, Medical University of Lublin, Jaczewskiego 4, 20-090 Lublin, Poland; \\ i.m.osuchowska@gmail.com (I.O.); maciejewski.r@gmail.com (R.M.) \\ 3 Department of Clinical Immunology, Medical University of Lublin, Jaczewskiego 8, 20-954 Lublin, Poland; \\ jakub.litak@gmail.com \\ * Correspondence: cezary.grochowski@o2.pl
}

Received: 30 March 2020; Accepted: 21 April 2020; Published: 27 April 2020

check for updates

\begin{abstract}
Central nervous system tumors are a significant problem for modern medicine because of their location. The explanation of the importance of microRNA (miRNA) in the development of cancerous changes plays an important role in this respect. The first papers describing the presence of miRNA were published in the 1990s. The role of miRNA has been pointed out in many medical conditions such as kidney disease, diabetes, neurodegenerative disorder, arthritis and cancer. There are several miRNAs responsible for invasiveness, apoptosis, resistance to treatment, angiogenesis, proliferation and immunology, and many others. The research conducted in recent years analyzing this group of tumors has shown the important role of miRNA in the course of gliomagenesis. These particles seem to participate in many stages of the development of cancer processes, such as proliferation, angiogenesis, regulation of apoptosis or cell resistance to cytostatics.
\end{abstract}

Keywords: glioblastoma multiforme; miRNA; RNA; glioma; high grade glioma; pediatric population; children

\section{Introduction}

Central nervous system tumors are a significant problem for modern medicine because of their location. It is estimated that about 250,000 patients receive inauspicious diagnoses each year [1]. In adults, approximately $32 \%$ of primary tumors show malignancy. Of these, glioblastoma multiforme (GBM) is the most common and also the most harmful diagnosis [2-5]. The standard treatment for this type of tumor is a combination of surgical resection, radiotherapy and chemotherapy [6,7]. Unfortunately, despite the implementation of appropriate therapy, attempts to improve patient prognoses and survival rates remain unsuccessful $[3,4,6,8,9]$. For this reason, many centers are conducting research in order to better understand the pathomechanisms of GBM development, which could allow us to find new treatments and improving existing ones. The explanation of the importance of microRNA (miRNA) in the development of cancerous changes plays an important role in this respect $[10,11]$.

miRNAs are small, single-stranded RNA molecules with a length of 21 to 23 nucleotides [12-14]. They are encoded by the cell genome, as well as normal genes, while RNA polymerase II is responsible for their transcription $[15,16]$. The number of miRNAs encoded by the human genome is very divergent. 
These values range from about 600 to over 1900 (http://www.mirbase.org/cgi-bin/browse.pl?org= hsa $[17,18])$. It is estimated that they regulate around a third of all protein-coding genes and participate in such crucial processes as proliferation, cell differentiation and the mechanisms of apoptosis [19-21]. Interestingly, more than half of the genes encoding miRNAs are located in fragile chromosomal sites and other areas consistent with the development of cancerous processes [22,23]. The regulation mechanism relies on silencing the expression of some genes through binding in order to target messenger RNA (mRNA) [24]. Each miRNA is complementary, with a specific biological target, which is the corresponding mRNA fragment (usually located within the $3^{\prime}$ untranslated region). After fusion, the translation process is inhibited, preventing the expression of the encoded gene $[25,26]$.

To this day, many authors have been able to demonstrate disturbances in the levels of various miRNAs in the course of GBM [26-31]. This applies to both the increased and decreased titers of miRNA compared to normal brain tissue [29,32-45] (Table 1). The significance of these differences has not yet been fully understood. In this study, we will try to introduce the role of miRNA in the pathogenesis of high-grade glioma among children.

Table 1. Presentation of microRNA (miRNA) molecules, divided into major groups of action: carcinogenesis modulants (apoptosis, invasiveness, angiogenesis, proliferation), tumor indicators (biomarkers), tumor development controllers (histological progression) and treatment effectiveness markers (treatment response). Arrows indicate $=$ whether the levels of miRNA are increased, decreased or both.

\begin{tabular}{|c|c|c|c|c|c|c|}
\hline $\begin{array}{c}\text { Apoptosis } \\
\text { (Tissue Level) }\end{array}$ & $\begin{array}{l}\text { Invasiveness } \\
\text { (Tissue Level) }\end{array}$ & $\begin{array}{l}\text { Angiogenesis } \\
\text { (Tissue Level) }\end{array}$ & $\begin{array}{l}\text { Proliferation } \\
\text { (Tissue Level) }\end{array}$ & $\begin{array}{l}\text { Biomarkers } \\
\text { (Tissue Level) }\end{array}$ & $\begin{array}{l}\text { Histological } \\
\text { Progression } \\
\text { (Tissue Level) }\end{array}$ & $\begin{array}{c}\text { Treatment } \\
\text { Response } \\
\text { (Tissue Level) }\end{array}$ \\
\hline $\begin{array}{c}\operatorname{miR}-10 \mathrm{~b} \downarrow \\
\operatorname{miR}-21 \downarrow \\
\mathrm{miR}-34 \mathrm{a} \uparrow \\
\mathrm{miR}-124 \downarrow \\
\mathrm{miR}-182 \uparrow \\
\mathrm{miR}-211 \uparrow \\
\mathrm{miR}-221 \uparrow \\
\operatorname{miR}-222 \uparrow \\
\operatorname{miR}-326 \downarrow \\
\operatorname{miR}-330 \downarrow \\
\operatorname{miR}-335 \downarrow\end{array}$ & 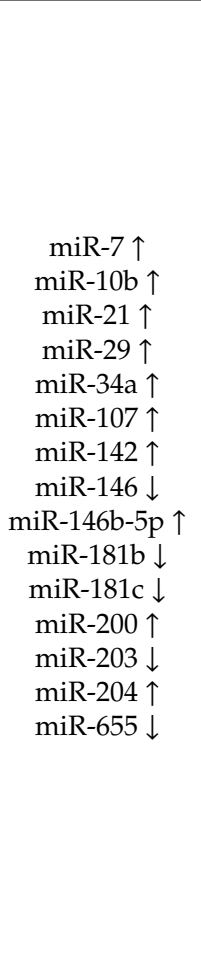 & $\begin{array}{c}\text { miR-7-5p } \downarrow \\
\text { miR-17-5p } \downarrow \\
\text { miR-21 } \uparrow \\
\text { miR-29a } \downarrow \\
\text { miR-93 } \uparrow \\
\text { miR-125b } \downarrow \\
\text { miR-128 } \downarrow \\
\text { miR-155 } \downarrow \\
\text { miR-186 } \downarrow \\
\text { miR-210-3p } \uparrow \\
\text { miR-296 } \uparrow \\
\text { miR-429 } \downarrow \\
\text { miR-675-5p } \downarrow\end{array}$ & $\begin{array}{c}\text { miR-7 } \downarrow \downarrow \\
\text { miR-19a } \uparrow \downarrow \\
\text { miR-21 } \uparrow \\
\text { miR-23 } \downarrow \\
\text { miR-29 } \downarrow \\
\text { miR-34 } \downarrow \\
\text { miR-101 } \uparrow \downarrow \\
\text { miR-107 } \downarrow \downarrow \\
\text { miR-122 } \downarrow \downarrow \\
\text { miR-124 } \downarrow \\
\text { miR-128 } \downarrow \\
\text { miR-137 } \\
\text { miR-140 } \downarrow \\
\text { miR-144 } \downarrow \downarrow \\
\text { miR-145 } \downarrow \downarrow \\
\text { miR-152 } \downarrow \downarrow \\
\text { miR-155 } \downarrow \\
\text { miR-181 } \downarrow \\
\text { miR-181c } \uparrow \downarrow \\
\text { miR-182 } \uparrow \downarrow \\
\text { miR-186 } \uparrow \downarrow \\
\text { miR-203 } \uparrow \downarrow \\
\text { miR-204 } \uparrow \downarrow \\
\text { miR-221 } \uparrow \downarrow \\
\text { miR-222 } \uparrow \downarrow \\
\text { miR-326 } \uparrow \downarrow \\
\text { miR-384 } \uparrow \downarrow \\
\text { miR-6500-3p } \uparrow \downarrow\end{array}$ & $\begin{array}{c}\text { miR-17 } \uparrow \\
\text { miR-19a } \uparrow \\
\text { miR-19b } \uparrow \\
\text { miR-21 } \uparrow \\
\text { miR-25 } \\
\text { miR-34a } \downarrow \\
\text { miR-92b } \uparrow \\
\text { miR-106b } \uparrow \\
\text { miR-125b } \uparrow \\
\text { miR-128a } \downarrow \\
\text { miR-130a } \uparrow \\
\text { miR-132 } \downarrow \\
\text { miR-155 } \uparrow \\
\text { miR-181a } \downarrow \\
\text { miR-181b } \downarrow \\
\text { miR-181c } \downarrow \\
\text { miR-182 } \uparrow \\
\text { miR-198 } \downarrow \\
\text { miR-219-5p } \downarrow \\
\text { miR-221 } \uparrow \\
\text { miR-329 } \downarrow \\
\text { miR-335 } \uparrow \\
\text { miR-338-3p } \downarrow \\
\text { miR-483-5p } \downarrow\end{array}$ & $\begin{array}{c}\operatorname{miR}-9 \uparrow \\
\operatorname{miR}-15 \mathrm{a} \uparrow \\
\mathrm{miR}-16 \uparrow \\
\mathrm{miR}-17 \uparrow \\
\mathrm{miR}-19 \mathrm{a} \uparrow \\
\mathrm{miR}-20 \mathrm{a} \uparrow \\
\mathrm{miR}-21 \uparrow \\
\operatorname{miR}-25 \uparrow \\
\operatorname{miR}-28 \uparrow \\
\operatorname{miR}-130 \mathrm{~b} \uparrow \\
\operatorname{miR}-140 \uparrow \\
\operatorname{miR}-184 \uparrow \\
\mathrm{miR}-210 \uparrow \\
\mathrm{miR}-328 \uparrow\end{array}$ & $\begin{array}{c}\text { miR-17-5p } \uparrow \downarrow \\
\text { miR-21 } \uparrow \\
\text { miR-19a } \uparrow \downarrow \\
\text { miR-19b } \uparrow \downarrow \\
\text { miR-100 } \uparrow \\
\text { miR-101 } \downarrow \\
\text { miR-139 } \downarrow \\
\text { miR-143 } \uparrow \\
\text { miR-155 } \uparrow \\
\text { miR-181a } \downarrow \\
\text { miR-182 } \downarrow \downarrow \\
\text { miR-193a5p } \uparrow \downarrow \\
\text { miR-200a } \uparrow \downarrow \\
\text { miR-200q } \uparrow \downarrow \\
\text { miR-203 } \downarrow \downarrow \\
\text { miR-204 } \downarrow \downarrow \\
\text { miR-221 } \downarrow \\
\text { miR-222 } \uparrow \downarrow \\
\text { miR-328 } \downarrow \downarrow \\
\text { miR-490 } \downarrow \downarrow \\
\text { miR-603 } \downarrow \downarrow \\
\text { miR-873 } \downarrow \downarrow\end{array}$ \\
\hline
\end{tabular}

\section{Invasiveness}

Tumor invasiveness is one of the aspects that is characteristic of GBM and is influenced by miRNA. It is conditioned by a number of features and mechanisms of the neoplasm process. These include epithelial to mesenchymal transition (EMT), which was first described in the 1980s in a paper about embryogenesis $[46,47]$. This involves changing the polarity of epithelial cells and their loss of ability to conduct cell-cell adhesion. As a result, their phenotype changes from epithelial to mesenchymal. 
This is manifested by a decrease in the expression of adhesive proteins such as E-cadherins, as well as the activation of new transcription factors, changes in the cytoskeleton of cells, the production of new enzymes capable of remodeling extracellular matrix components and the presentation of characteristic markers ( $\mathrm{N}$-cadherin, fibronectin, vimentin). The result is a decrease in the integrity of the environment and an increase in cell migration and tumor invasion [48-50]. In recent years, it has been discovered that miRNA can also influence the course of epithelial to mesenchymal transition. Studies on pancreatic cancer cell lines have shown that the presence of miR-655 causes EMT inhibition, resulting in decreased tumor cell migration and increased expression of E-cadherins. This process occurs through the effect on the TGF- $\beta$ axis and the ZEB1 transcription factor, both of which normally promote epithelial to mesenchymal transition [51]. Similar relationships were observed for gliomas. They concerned, among others: miR-10-b, miR-21, miR-146 and miR-181b. The presence of some of them showed the effect of increasing tumor invasion (miR10-b, miR21), while others inhibited cell migration (miR-146) [52-55]. This also applies to high-grade gliomas, such as glioblastoma [56,57]. In studies conducted by Liao et al. on GBM cells, a decrease in miR-203 levels has been shown to be associated with increased EMT activity. The reason for this association was the effect of miR-203 on snail family transcriptional repressor 2 (SNAI2) [58]. It is an embryonic zinc finger protein whose function is to inhibit the expression of E-cadherins [59-61]. Liao et al. have shown that miR-203 causes the inhibition of SNAI2 expression, contributing to an increase in EMT activity and tumor invasion [58]. Furthermore, the researchers pointed out the connection between this relationship and the resistance of neoplasm cells to anticancer therapy, which is consistent with other papers describing SNAI2 [62,63]. The association of miRNA with the ZEB and SNAI2 axis was also suggested in other observations. Chang et al. indicated that tumor suppressor p53, through the activation of miR-200 may cause the inhibition of epithelial mesenchymal transition, affecting ZEB and SNAI2 production [64].

Matrix metalloproteinases (MMPs) are a group of proteins of special importance in the mechanisms of EMT and tumor invasion. These are endopeptidases involved in the regulation of cell metabolism and tissue remodeling processes $[65,66]$. Disorders of their function may cause the impairment of cell integrity and degradation of the extracellular matrix. This allows cells to disengage from the original environment and migrate, thereby increasing tumor invasiveness. The role of some of them (MMP-2, MMP-9, MMP-14) has been proved in the process of developing high grade gliomas [67-71]. In studies conducted by Gabriely et al., the effect of miR-21 on tumor aggressiveness was observed. Researchers have pointed to the ability of miR-21 to increase MMP activities by affecting the expression of a number of genes. The most important role was assigned to reversion-inducing-cysteine-rich protein with kazal motifs (RECK) and tissue inhibitor of metalloproteinases 3 (TIMP3). These are the genes responsible for the negative regulation of some MMPs. The inhibition of miR-21 has been shown to lead to an increase in RECK and TIMP3 levels, resulting in a decrease in MMP activities. This applied to both in vitro samples, as well as the human model of gliomas in mice. Interestingly, researchers suggested that only RECK is directly inhibited by miR-21 [53,72]. Other observations have shown that the effect of miR-21 on tumor invasion can also take place by inhibiting tumor suppressor genes ANP32A, SMARCA4 and sprouty homolog 2 (Spry2) [73,74]. The promotion of glioblastoma invasion by affecting metalloproteinases has also been demonstrated for miR-10b. The observations of Sun et al. have shown that these molecules affect HOXD10, which influences the expression of MMP14 and uPAR, contributing to greater tumor cell migration [75]. This fact is consistent with other studies reporting the correlation between the histological stage of gliomas and miR-10b expression [55].

On the contrary, in the study of Li et al. on glioblastoma cell lines, it was shown that miR-146b-5p has a negative effect on the activity of metalloproteinases (MMP2 and MMP16). The result was the inhibition of cell migration and tumor invasion [53]. Other researchers have also repeatedly pointed out the effect of miR-146 on the inhibition of tumor metastasis by suppressing MMPs [76-78]. The relationship between the presence of miRNA and the activity of metalloproteinases (MMP2, MMP3, MMP9, MMP12, MMP13, ADAM9) was demonstrated in many other observations conducted on gliomas, including glioblastoma [57,79-85]. 
Another example of miRNA associated with tumor invasion is miR-7. It has been shown that, in glioblastoma, its level is lowered compared to normal tissue and that it performs suppressor functions $[44,86]$. In addition, in this case, it was observed that it inhibits the activity of metalloproteinases (MMP2, MMP9) [26,56]. Moreover, it has an influence on metastasis by affecting certain genes such as RAF1, FAK, phosphatidylinositol 3-kinase (PI3K) and epidermal growth factor receptor (EGFR) $[44,56,87,88]$. Epidermal growth factor (EGF) is a protein, which, through binding to the receptor (EGFR) on the surface of cells, has a very large impact on their metabolism [89]. Phosphorylation of the transmembrane EGF receptor activates further signaling pathways, which include Akt, JNK and mitogen-activated protein kinase (MAPK) pathways, affecting cell proliferation and DNA synthesis, as well as other processes associated with tissue metabolism [90]. Receptor mutations often lead to its continuous activation, resulting in an uncontrolled increase in the number of cells [91]. In primary glioblastoma, EGFR is considered overexpressed in $63 \%$ of cases [92]. For GBM, the EGFRvIII-type mutation is characteristic [93-96]. In cancer cells, disorders in the EGFR are usually associated with an increase in cell migration, an increase in angiogenesis and an increase in tumor invasion [69,97,98]. A study performed by Kefas et al. confirmed that miR-7 levels are lowered in glioblastoma. Furthermore, they showed that miR-7 can inhibit the EGF receptor, thereby contributing to the inhibition of viability and the invasiveness of GMB cells. This process takes place both through the influence on the receptor itself as well as through insulin receptor substrates 1 and 2 (IRS-1 and IRS-2), which are regulators of the Akt pathway [44].

\section{Apoptosis}

Another characteristic feature of glioblastoma is the disorder of the mechanism of natural programmed cell death. Moreover, in this case, specific miRNA regulates tumor progression by inhibiting or increasing apoptosis [26]. The group of particles with antiapoptotic effects in the case of glioblastoma includes, among others, the previously described miR-21. Its effect on the mechanism of apoptosis includes many pathways, such as TGF- $\beta$, p53 and the mitochondrial apoptotic pathway [72].

p53 is a tumor suppressor protein that plays key roles in the regulation of many aspects of cell metabolism, such as the cell cycle, genomic stability and apoptosis [99]. A similar role to p53 is played by its homologues: tumor protein p63 and tumor protein p73 [100]. The activation of p53 leads to the activation of numerous signal pathways containing (among others): junction-mediating and regulatory protein (JMY), death-associated protein 6 (DAXX), heterogeneous nuclear ribonucleoprotein K (HNRPK) and tumor protein p53-binding protein 2 (TP53BP2) [101-104]. Mutations in the p53 gene and disturbances in assisting proteins may be associated with abnormal cell division, the inhibition of their apoptosis and the impairment of internal repair mechanisms. So far, it has been possible to demonstrate their role in this type of disorder in the pathomechanism of most of the studied cancers [105]. This also applies to glioblastoma. Papagiannakopoulos et al. showed that the potential targets of miR-21 particles are p63 (p53 homolog), as well as HNRPK, TP53BP2, TOPORS, DAXX and JMY [72]. The overexpression miR-21 therefore leads to the disorder of these pathways, leading to pro-proliferative and antiapoptotic actions (Figure 1).

The TGF- $\beta$ axis also plays an important role in the regulation of apoptosis in glioblastoma. It has been reported that miR-21 can regulate this pathway through the indirect impact of TGFB1/2 and the direct interaction of the receptors TGFBR2/3. Furthermore, it also affects the apoptotic mediator DAXX. Therefore, it constitutes a doubly important element, participating in the regulation of apoptosis both through the TGF- $\beta$ axis and the p53 activation pathway. The effect of miR-21 on the mitochondrial apoptotic pathway is achieved through its interaction with APAF1 and PPIF [72]. 


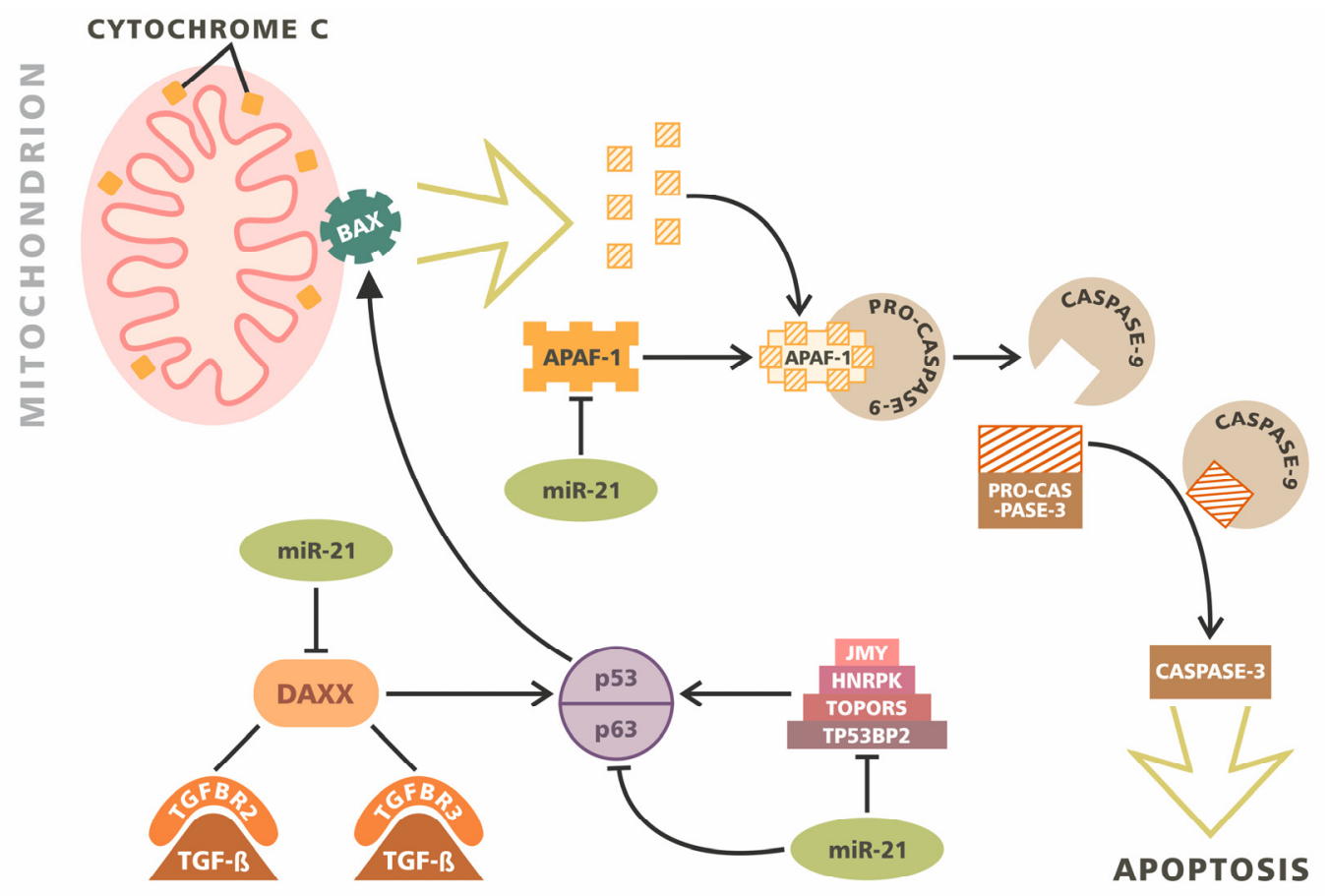

Figure 1. Multimodal inhibitory role of miR-21 in apoptosis. miR-21 directly inhibits the cascade of p53/p63 regulatory proteins, such as junction-mediating and regulatory protein (JMY), heterogeneous nuclear ribonucleoprotein $\mathrm{K}$ (HNRPK), TOPORS and tumor protein p53-binding protein 2 (TP53BP2). Additionally, miR-21 interacts with death-associated protein 6 (DAXX), the protein modulating TGF-beta/TGFBR2/3 signaling. The activation of BAX results in cytochrome $\mathrm{C}$ release. APAF-1 binds free cytochromes, creating APAF-1/PRO-CASPASE-9 complex. miR-21 inhibits APAF-1 expression and further activation of caspases. The activated CASPASE-9 cleaves PRO-CASPASE-3 to a mature form. CASPASE-3 triggers apoptosis. The miR-21 molecule indirectly limits CASPASE-3 activation and reduces apoptosis.

Caspases are another group of enzymes involved in the regulation of programmed cell death. They exhibit cysteine protease activity, leading to apoptosis [106]. Studies by Chen et al. on glioblastoma cell lines have shown that reducing miR-21 levels can lead to an increase in caspase activity, resulting in the activation of the mechanism of apoptosis [34]. This was also confirmed in other studies pointing out the special role of caspase 3 and caspase 9 in this mechanism [107]. Furthermore, other miRNAs can also affect the activity of this group of enzymes. Austhakar et al. described the role of miR-211 in the activation of caspase 3 and caspase 9 in GBM [81]. Similar conclusions were made by Koueri et al. regarding miR-182 [108]. In addition, the significance of miRNA in the regulation of apoptosis conditioned by caspase activity in gliomas was also reported by other researchers $[79,109,110]$. The effect of miRNA-programmable cell death also takes place with the help of other mechanisms. It has been shown that miR-221 and miR-222 can affect the p53 pathway by interacting with the p53-upregulated modulator of apoptosis (PUMA) [26]. It is a protein belonging to the Bcl-2 family, and is capable of activating apoptosis mainly through the activation of $\mathrm{p} 53$ protein $[111,112]$. Research by Zhang et al. on glioblastoma cells showed that PUMA is the direct target of miR-221 and miR-222. An increase in the level of these miRNAs resulted in a decrease in PUMA activity and an increase in cell survival, while their reduced expression resulted in increased apoptosis [113]. Other studies also indicated the involvement of miR-221 and miR-222 in the regulation of programmable cell death in mechanisms independent of the p53 axis [114]. miR-335 is another molecule with antiapoptotic properties. Shu et al. described its effect on the disheveled-associated activator of morphogenesis 1 (DAAM1) in human malignant astrocytomas. DAAM1 is a potential tumor suppressor protein that inhibits the growth and invasiveness of the tumor. The inhibition of miR-335 leads to the induction of apoptosis, growth arrest 
and a decrease in tumor cell invasiveness in both in vivo and in vitro observations [115]. miR-17 has also been shown to have the ability to inhibit autophagy in GBM cells [116].

\section{Angiogenesis}

The mechanism of angiogenesis involves the formation of a network of new blood vessels based on existing ones [117]. It is particularly intensified in the case of high-grade tumors, including glioblastoma [118-120]. Studies carried out in recent years suggest that miRNA may also affect angiogenesis [121].

Numerous observations have shown that mechanisms of neovascularization can be both dependent and independent of the occurrence of hypoxia [69,122-127]. Researchers indicate that the main mechanism responsible for the formation of new blood vessels in glioblastoma is vascular endothelial growth factor (VEGF), which is directly related to hypoxia-inducible factor (HIF). HIFs are transcription factors that respond to fluctuations in the oxygen concentration in the cell environment [128-130].

A decrease in the level of HIF in response to hypoxia and the inactivation of prolyl hydroxylases cause the release of VEGF. The goal of this pathway is to counteract hypoxia by providing greater access to oxygen resources from the network of new vessels $[69,125,131,132]$. Studies performed by Hermansen et al. on patients with gliomas have shown that, within the tumor, increased levels of HIF-1 $\alpha$ and VEGF are accompanied by an increase in miR-21 expression [133]. A similar mechanism was shown by Shi et al. regarding miR-128. However, in their observations, increased miRNA expression caused the opposite effect and a decrease in the severity of angiogenesis [134]. Wang et al. showed that, in the case of miR-143, this axis can be influenced by N-RAS [135]. The relationship between hypoxia-dependent angiogenesis and miRNA expression has also been proven in glioblastoma. Agrawal et al. showed that miR-210-3p expression correlates well with HIF-1 $\alpha$ levels, as well as with other HIFs (HIF-3 $\alpha$ ). miR-210-3p expression increases the level of VEGF and the activity of carbonic anhydrase 9 (CA9), resulting in the development of the vascular network [136]. Wurdinger et al. suggested the effect of miR-296 on the induction of angiogenesis in GBM [137]. Moreover, Smith et al. showed a relationship between reduced miR-125-b expression in glioblastoma cells and an increase in myc-associated zinc finger protein (MAZ). MAZ is involved in the regulation of VEGF, which results in increased angiogenesis [138]. Numerous studies have reported the miRNA and VEGF interplay in glioma patients $[82,139,140]$ (Figure 2).

VEGF is not the only mechanism affecting the severity of angiogenesis, which is affected by miRNAs. miR-93 is a member of the miR-17 family and its expression is increased in glioblastoma cells. Recent observations have shown that miR-93 is involved in the regulation of angiogenesis by affecting the expression of integrin- $\beta 8$ [141]. It is a protein whose function is mediated by cell-cell and cell-extracellular matrix interactions $[26,141]$. Research by Tchaich et al. showed a relationship between the severity of angiogenesis and tumor invasion and the expression of integrin- $\beta 8$. High levels of this protein were characteristic of lowly angiogenic and highly invasive neoplasms, while low expression meant a high capacity for vascular network development and low tumor invasiveness [142]. Observations made by Fang et al. on glioblastoma cells showed that integrin- $\beta 8$ is one of the targets of miR-93 activity. The upregulation of miR-93 expression in the human glioblastoma cell line U87 resulted in an increase in vascularization [141]. An association with angiogenesis has also been suggested for other miRNAs belonging to the miR-17 family, such as miR-17-5p and miR-20a, as well as miR-29a, miR-155, miR-186, miR-429 and miR-675-5p [143-148]. 


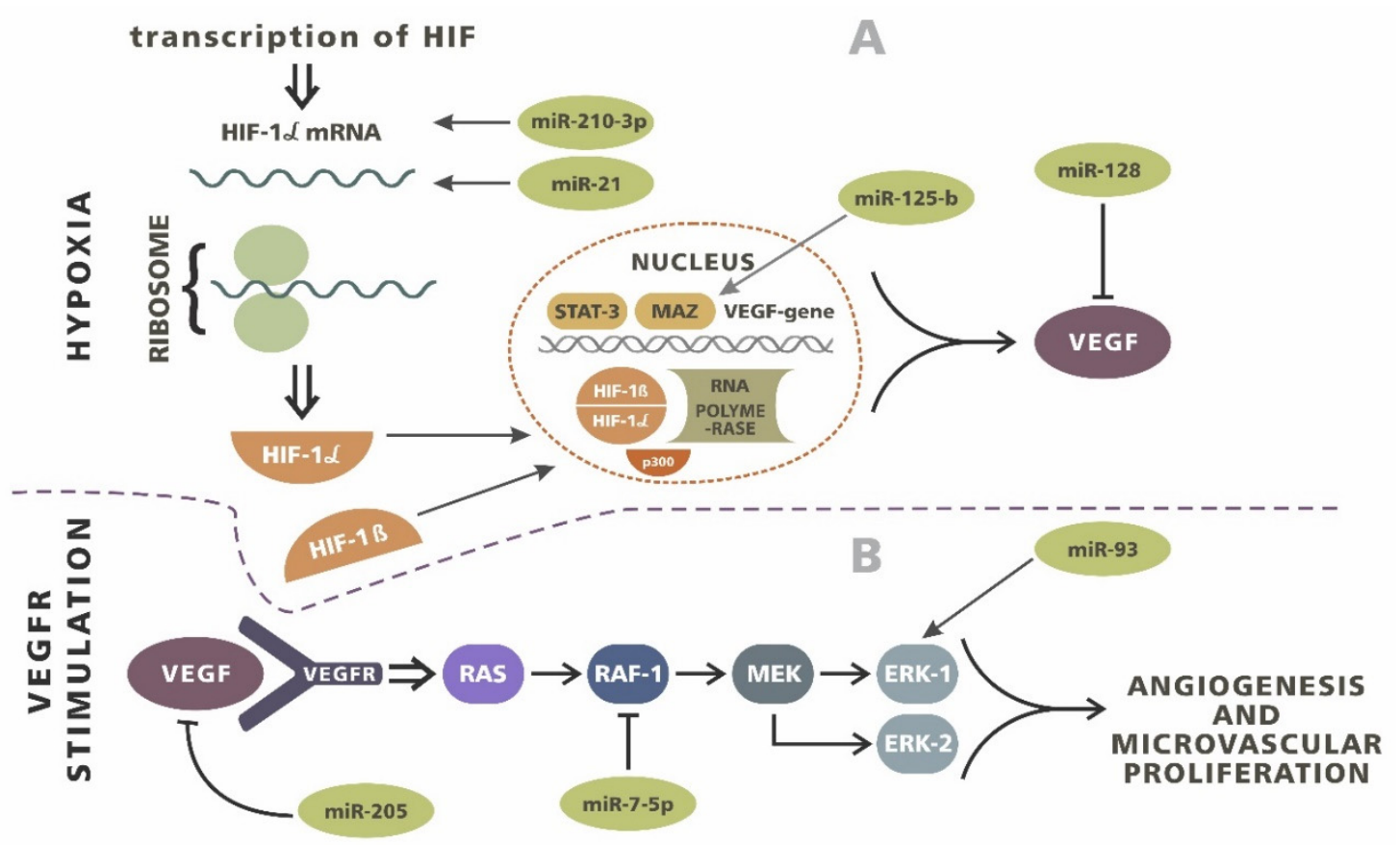

Figure 2. The influence of miRNA on angiogenesis process. (A) Hypoxia induces the transcription and Table 1. molecules. miR-210-3p and miR-21 act as a costimulators, intensifying expression. HIF-1 $\alpha$ cooperates with HIF-1 $\beta$ subunits and various complementary molecules such as p300, STAT-3 and myc-associated zinc finger protein (MAZ) during the transcription of vascular endothelial growth factor (VEGF). miR-125-b interplays with MAZ and a reduced level of miR-125-b results in an increase in MAZ and VEGF expression. miR-128 inhibits VEGF translation directly. (B) VEGF/VEGF receptor (R) axis signals through RAS/RAF-1/MEK/ERK-1/ERK-3. The promotion of this pathway results in intensive angiogenesis and microvascular proliferation. miR-205 inhibits VEGF/VEGFR interplay and miR 7-5p inhibits RAF-1. Both molecules significantly reduce angiogenesis in glioma. miR- 93 influences the expression of molecules by promoting microvascular growth.

One of the characteristic features of glioblastoma is also microvascular proliferation. This is useful for distinguishing gliomas with a lower degree of malignancy from GBM [75,87]. Liu et al. compared miR-7-5p levels in GBM microvessels and in healthy brain capillaries. Observations showed that miR-7-5p levels were significantly reduced for GBM. Moreover, an inverse correlation was observed between RAF1 and miR-7-5p levels due to the changes in the vascularization of the samples [87]. RAF1 is a serine/threonine kinase whose actions are based on the effect of mitogen-activated protein kinase (MAPK) activity, as it is a link in the Ras-Raf-MEK-ERK chain. Its role has already been observed in the pathomechanism of other cancers [149-155]. It has also been shown that increased RAF1 levels are present in human glioblastoma samples and that they may be associated with microvascular proliferation [156]. Moreover, Liu et al. have suggested that RAF1 is one of the potential targets of miR-7-5p. Increasing miR-7-5p levels in human umbilical vein endothelial cells resulted in a significant decrease in RAF1 expression [87].

\section{Proliferation and Immunology}

miRNAs also affect other processes that are important for the pathogenesis of tumors, such as cell cycle regulation and the control of cell proliferation. As previously mentioned, an example of this mechanism is miR-7 and its antiproliferative activity through the Akt axis [44,87]. Another particle with a similar effect is miR-128. It has been shown that, in glioblastoma, titers in the tissues of this miRNA usually remain low [157]. Its anti-proliferative effect is possible due to its influence on a number of metabolic pathways due to its effect on the expression of WEE1, EGFR, E2F3A and MSI1 [29,157-159]. E2F3A acts as a transcription factor and cell cycle activator through the retinoblastoma protein (RB1) 
and cyclin-dependent kinase (CDK)/cyclin complex genes. miR-124 and miR-137 also contribute to the regulation of this pathway and the cell cycle itself. They inhibit CDK6 activity and RB1 phosphorylation, thereby decreasing E2F pathway signaling [26]. miR-137 may also affect another gene involved in the regulation of proliferation, which is the previously mentioned MSI1 [160]. This is done through nuclear casein kinase and cyclin-dependent kinase substrate 1 (NUCKS1), which is a highly phosphorylated nuclear DNA-binding protein. It plays a role in recombination and DNA repair processes, and also acts as a substrate for cyclin-dependent kinase (CDK) [161-165]. The disorder of its expression has been associated with the pathogenesis of cancers, including brain tumors [166-172]. Its role in the regulation of proliferation has also been noted for many other miRNAs. This group includes, among others: miR-34a (via CDK6, CCND1 and NOTCH), miR6500-3a, let7 (via CCK-8), miR-21 (via PDCD4 and CASC2), miR-221 (via p27Kip1), miR-222 (via p27Kip1), miR-204 (via ATF2 and EZRIN), miR-23, miR-145 (via CTGF, NEDD9, NOTCH and platelet-derived growth factor receptors (PDGFR)), miR-181 (via NOTCH and SALL4), miR-29 (via QKI-6), miR-19a (via RUNX3), miR-101 (via SOX9), miR-107 (via NOTCH), miR-122 (via SOX2 and Wnt/ $\beta$-catenin pathway), miR-140, miR-144, miR-152 (via RUNX2), miR-155 (via Wnt/ß-catenin pathway), miR-182, miR-203 (via GAS41 and PCDH2), miR-186, miR-326, miR-384 [79,84,109,173-204].

miRNA also affects the regulation of the body's immune processes. In terms of glioblastoma development, the programmed death ligand 1 (PD-L1) pathway is a particularly important factor [69,205-208]. The expression of PD-L1 on the surface of GBM cells causes the activation of the programmed death-1 (PD-1) receptor. As a result, the inhibition of $\mathrm{T}$ cell activity occurs, resulting in a decrease in the immune response and an increase in tumor invasiveness. This axis is regulated by many mechanisms, which also include miRNA expression [69]. A literature analysis carried out by Wang et al. pointed out the existence of 49 examples of miRNA participating in the regulation of the PD-1/PD-L1 axis. This concerned many cancers such as lung cancer, prostate cancer, kidney cancer, osteosarcoma, gastric cancer, melanoma, endometrial cancer, breast cancer and bladder cancer [209]. A similar mechanism, however, also occurs in gliomas. Research conducted by Wei et al. have shown that miR-138 can bind PD-1 by affecting the body's immune response. Moreover, tests on animal models showed that miR-138 treatment may positively affect the results of treatment and reduce the value of tumor markers [210]. However, further research is needed to find out the exact characteristics of these processes for glioblastoma.

\section{High Grade Gliomas and miRNA in the Pediatric Population}

\subsection{Expression of mRNA in Pediatric and Adult Population}

Most studies analyzing the effect of miRNA on the pathogenesis of high-grade gliomas (HGGs) focus primarily on adult patients. To this day, relatively few observations have been made on the pediatric population. Studies that do refer to the pediatric population generally discuss such cancers as medulloblastoma, osteosarcoma, atypical teratoid/rhabdoid tumor (ATRT), leukemia and Ewing's sarcoma [211-220]. Some researchers hae also focused their observations on brain tumors [221-233]. Pediatric HGGs constitute about $8-10 \%$ of all HGGs and, as in adults, these gliomas are characterized by high growth dynamics and a poor prognosis [234-237].

The first large-scale analysis of the occurrence of miRNA in the pediatric population was conducted by Birks et al. in 2011. They examined the differences between miRNA expression in pediatric brain tumors (ATRT, ependymoma, glioblastoma, medulloblastoma, and pilocytic astrocytoma) and normal tissue. The analysis was performed using the microarray method, taking into account 470 human miRNAs. In the case of pediatric GBM, the authors showed a significant reduction in miR-129 levels, as well as the overexpression of miR-25 and miR-142-5p [238]. These observations were consistent with previous work conducted on the adult patient population [31,33]. Distinctions in the occurrence of miR-129, miR-25 and miR-142-5p in the pediatric population have also been shown in a similar analysis by Miele et al. In this case, differences in miRNA levels between pediatric high-grade gliomas (pHGG), 
normal brain tissue and adult high-grade gliomas (aHGG) were studied. More miRNAs (754) were included in this, analysis of which 436 were expressed in HGG. Taking into account only the pediatric population, 152 miRNAs were found. The authors also showed that differential expression between pHGG and aHGG occurred in 228 cases. The most elevated miRNAs in pediatric samples compared to the adult population and normal brain tissue included: miR-15a, miR-17, miR-18a, miR-19a, miR-19b, miR-20, miR-27a, miR-92, miR-100, miR-106a, miR-195 and miR-497 (Tables 2 and 3) [239].

Table 2. Expression of particular miRNA molecules detected in pediatric high-grade glioma (HGG) population.

\begin{tabular}{cc}
\hline Overexpression & Reduced Expression \\
\hline miR-15a & \\
miR-17 & miR-7-5p \\
miR-18a & miR-124-5p \\
miR-19a & miR-129-2-3p \\
miR-19b & miR-137 \\
miR-20 & miR-138-2-3p \\
miR-27a & miR-139-3p \\
miR-92 & miR-203a \\
miR-100 & miR-218-5p \\
miR-106a & miR-329-3p \\
miR-195 & miR-770-5p \\
miR-497 & \\
\hline
\end{tabular}

Table 3. Expression of particular miRNA molecules detected in adult HGG population.

\begin{tabular}{cc}
\hline Overexpression & Reduced Expression \\
\hline & miR-7 \\
miR-10b & miR-106a \\
miR-21 & miR-124 \\
miR-25 & miR-128 \\
miR-26a & miR-129 \\
miR-221 & miR-137 \\
miR-222 & miR-139 \\
miR-335 & miR-181a \\
miR-451 & miR-181b \\
miR-486 & miR-218 \\
miR-501-3p & miR-323 \\
& miR-328 \\
\hline
\end{tabular}

An even more extensive analysis was carried out by Jha et al. They looked for expression of 1733 mature miRNA and 1658 pre-miRNAs in pediatric high-grade gliomas. Differences compared to the control samples were found in 266 cases. Overexpression concerned 55 mature miRNAs and two pre-miRNAs. The largest differences were found for miR-10b-5p, miR-891a-5p, miR-182-5p, miR-21-5p, miR-424-3p, miR-130b-3p, miR-130b-5p, miR-106b-3p and miR-4521. The opposite trend was shown in 71 mature miRNAs and 14 miRNA precursors, showing a reduced expression in the samples tested. This was most noticeable in the case of miR-7-5p, miR-137, miR-218-5p, miR-129-2-3p, miR-203a, miR-138-2-3p, miR-139-3p, miR-124-5p, miR-329-3p and miR-770-5p. In most cases, these results were consistent with the observations made in the adult population [240]. In the years that followed these studies, similar relationships were also studied by Giunti et al. In this case, differences in the expression of miR-137, miR-216a, miR-490, miR-501-3p, miR-521, miR-525-3p, miR-672, miR-873, miR-876-3p and miR-448 were demonstrated [172]. Another analysis was carried out by the team of Liang et al. In their work, they described the difference in miRNA expression by comparing pediatric low-grade gliomas (pLGG) with pediatric high-grade gliomas. They showed that significant overexpression in highly 
malignant tumors concerned only miR-17-5p and miR-561-5p, whereas a reduced level was detected for miR-137 and miR-6500-3p [174] (Table 4).

Table 4. Expression of particular miRNA molecules detected in pediatric HGG population compared with pediatric HGG population.

\begin{tabular}{cc}
\hline Overexpression & Reduced Expression \\
\hline miR-17-5p & miR-137 \\
miR-561-5p & miR-6500-3p \\
\hline
\end{tabular}

\subsection{Tumorgenesis-Similarities and Differences}

The differences presented in the above studies are associated with the different courses of tumorgenesis in adult and pediatric glioblastomas. For the adult population, there are two GBM subtypes:

- Primary-these are tumors that develop rapidly de novo;

- Secondary - these are derived from the evolution of low-grade gliomas that acquire malignancy.

The different starting point of tumorgenesis also causes discrepancies in genetic profiling and the molecular pathways of tumor metabolism. Primary GBMs are often characterized by mutations in the phosphatase and tensin homolog deleted on chromosome ten (PTEN) range and EGFR amplification, while, in secondary glioblastoma, we are more often dealing with TP53 mutations [8,176,237-239,241-248]. An analysis of the activity of pediatric GBM signaling pathways shows that, in this manner, they are similar to the secondary subtype [172]. This also applies to PTEN status and the associated phosphatidylinositol 3-kinase (PI3K) pathway. The activation of PI3K results in the formation of phosphatidylinositol-3,4,5,-triphosphate (PIP3), which results in the phosphorylation of Akt and its location in the plasma membrane. This transformation can lead to the activation of the kinase function, leading to uncontrolled cell proliferation and the inhibition of apoptosis as a result of tumor transformation [248-251]. The PTEN gene, which is a suppressor gene and a natural PI3K/AKT axis inhibitor, plays an important role in regulating this pathway $[252,253]$. It encodes an enzyme with phosphatase activity, which is capable of dephosphorylating PIP3, leading to the inhibition of Akt activity. Mutations in the PTEN gene leading to its abnormal function, resulting in the continuous activity of Akt and leading to the tumorogenesis process [254]. This phenomenon has been observed in gliomas, including multiform glioblastomas [255]. Moreover, PTEN mutations are relatively common in the adult population (they occur in about $50 \%$ of cases), while they are rare among children $[237,256-259]$. Observations made in recent years have shown that the regulation of the expression of this gene may also be affected by miRNAs. Studies of the adult population have revealed that the miRNAs that may affect regulation include miR-21, miR-26, miR-221, miR-222 [260-262]. Observations made by Miele et al. show that a similar phenomenon may also apply to the pediatric population. In their work, the authors suggested that the overexpression of the miR-17-92 cluster may cause the quenching of PTEN gene activity. The effect of this is an increase in cell proliferation and the acceleration of the tumor processes [239]. The miR-17-92 cluster is a larger group of miRNAs comprising six families, which include miR-17 (miR-17, miR-20a), miR-18 (miR-18a), miR-19 (miR-19a, miR-19b), and miR-92 (miR-92a) [263]. Its overexpression in the pediatric population was also noted in a paper by Jha et al. [240]. The attention of Miele et al. was also drawn to the effect of the same miRNA group on the expression of the retinoblastoma protein (RB1) gene [239]. It is a suppressor gene responsible for the regulation of the cell cycle [264]. RB1 mutations occur in glioblastomas in children, but they are less common than in the adult population $[258,259]$. Miele et al., in their work, showed that cluster miR-17-92 can silence the action of the RB1 gene, contributing to the intensification of gliomagenesis [239]. It is worth noting that the authors also emphasized the impact of this group of miRNAs on the Sonic Hedgehog pathway involved in the transmission of information on embryonic cell differentiation $[239,265]$. Many authors have pointed out the role of the Sonic Hedgehog pathway in controlling cell proliferation via the miR-17-92 cluster in both physiological brain development and 
tumor pathogenesis [214,266-268]. This also applies to gliomas in adults [266,267]. Miele et al. showed the disorders of this pathway in the pediatric population [239].

\subsection{The Role of Growth Factors}

Growth factor receptors are other elements of the PI3K axis that are involved in its activation. These include EGFR, EGFRvIII and platelet-derived growth factor receptors (PDGFR). They are also factors that can differentiate between both primary and secondary glioblastoma, as well as between aGBM and pGMB. The occurrence of EGFR overexpression in the pediatric population, which is characteristic of the primary subtype, is rarer (compared to the adult population) and the upregulation of PDGFR is more frequent [269-272]. As mentioned earlier, EGFR is a receptor protein located in the cell membrane that is involved in the activation of a number of signaling pathways. It is estimated that overexpression occurs in $30-50 \%$ of glioblastomas in the adult population, but overexpression only occurs in about $3 \%$ of glioblastomas in children $[237,241,273]$. PDGFR is involved in the regulation of cell proliferation and differentiation, as well as angiogenesis [274,275]. Both types of receptors play important functions in the metabolism of cells, but studies on a mouse model suggest that PDGF is the most important in the induction of gliomagenesis [276-279]. Interestingly, the work of Yang et al. suggests that miRNA may also be involved in the regulation of these signaling pathways. In their experiment, conducted on glioblastoma cells and glioma stem cell (GSC) lines, the authors demonstrated the ability of miR-29a to affect PDGF expression, thereby inhibiting growth and the ability of cancer cells to migrate, inducing their apoptosis [280]. Moreover, the observations of Costa et al. in a study performed on glioblastoma cells have shown that PDGF alone can affect the expression of some pro- and anti-oncogenic miRNAs. They showed the inhibitory effect of PDGF-B on miR-21 and miR-128 [281]. This demonstrates the complexity of the glioblastoma pathomechanism and emphasizes the need for further research into this matter. Data regarding the significance of the PDGF axis in gliomagenesis have also been confirmed by a large analysis of genomic imbalances in childhood high-grade gliomas by Pough et al. In their studies, PDGFR expression was high, while EGFR was significantly underexpressed. Moreover, the authors noted the lack of IDH1 hotspot mutation [241]. IDH status is another feature of the glioblastoma subtype, the expression of which varies between age groups. The IDH gene, with its two isoforms (IDH1 and IDH2), encodes isocitrate dehydrogenase, which is the enzyme responsible for the oxidative decarboxylation of isocitrate. Its mutation causes the transformation of $\alpha$-ketoglutarate to (D)-2-hydroxyglutarate, which results in the hypermethylation of DNA and histones, which may contribute to tumor development [282-284]. These types of changes are rare in pGBS $(<10 \%)$, while their occurrence in the adult population is very common $(98 \%)[241,272,285-293]$. Furthermore, they are also much more common in secondary, rather than in primary, glioblastoma [286,290,294,295]. In observations carried out by Balss et al. involving 14 children with glioblastoma, it was shown that the IDH1 mutation was present in only one case [290]. Convergent results were received by Hartmann et al. in a study that examined 1010 patients with diffuse gliomas. In the pediatric population, no IDH2 mutations were found, while IDH1 mutations were very rare in this patient group [296]. In a more detailed analysis of 43 patients with high-grade gliomas, Pollack et al. indicated that the IDH1 mutation does not occur in children under 14 years of age. In older children the mutation was reported in 35\% of cases [297]. This is consistent with the results of other authors and emphasizes the importance of IDH status as a distinctive feature of high-grade gliomas in adults and children $[285,286]$. The miRNA assay may be helpful in identifying IDH. Wang et al. determined 23 miRNAs, whose presence determined the IDH1 mutation in glioblastoma cells. Moreover, they showed that they also determine the course of the disease. However, it should be noted that these observations were carried out in the adult population [298]. 


\subsection{Epigenetic Nature of Glioblastoma}

Sturm et al. proposed the division of glioblastomas into six subgroups due to their epigenetic nature. They also emphasized the IDH mutation status as a characteristic of GBM in the pediatric population. Moreover, they noted the mutually exclusive relationship between the IDH1 and H3F3A mutations [293]. $\mathrm{H} 3 \mathrm{~F} 3 \mathrm{~A}$ is a gene encoding $\mathrm{H} 3.3$ histones, which are nuclear proteins with an important role in the regulation of transcription and replication [299]. Many studies have demonstrated that mutations in this gene are often found in the case of glioblastomas in the pediatric population [300,301]. Wu et al., in their study, observed the prevalence of H3.3 alterations in 50 samples of pediatric Diffuse Intrinsic Pontine Gliomas (DIPGs) and 36 non-brainstem pediatric glioblastomas. The results showed that the H3F3A mutation affected $78 \%$ of DIPGs samples and $22 \%$ of glioblastoma [302]. Observations carried out by Schwartzentruber et al. on 48 samples of pediatric glioblastoma showed even greater prevalence of this type of lesion, with it affecting $31 \%$ of the samples [303]. The absence of the IDH1 mutation and the relatively high prevalence of the H3F3A mutation (21.4\%) in pediatric high-grade glioma has also been confirmed in the work of Jha et al. Moreover, the authors noted the association of the H3F3A mutation with changes in miRNA levels among those patients. They identified 62 examples of those particles, which tissue titers were increased in the presence of mutations, and 35 which were low. Higher-level particles included miR-15a, miR-30e, miR-178c and miR-424 and concerned the K27M mutation. miRNAs, which titers depend on the status of the H3F3A mutation, were associated with the regulation of expression of genes responsible for cell proliferation and apoptosis. This group included FOXO1, FOXG1, CDK6 and MEIS. The authors also suggested that the gene expression profile with the K27M H3F3A mutation may be induced by the presence of miRNA [240]. An accurate understanding of this mechanism requires further research.

Sturm et al., in their work, also drew attention to the association of the H3.3 mutation with the TP53 mutation [272]. In the adult population, this type of mutation is less common, while among children with high grade gliomas, its prevalence is around $64 \%$ [240,304]. In their work, Jha et al. analyzed levels of miRNA depending on the mutation status of the TP53 gene. They showed that 63 miRNAs are specific for TP53-mutant cells. Overexpression affected 35 of them, while 28 were lowered [240]. These results were consistent with the analysis carried out by Ganci et al. for head and neck squamous cell carcinoma patients [305].

Studies on the pediatric population have shown a number of other pathways that are influenced by miRNA regulation. In addition to the axes mentioned above, Jha et al. noted the contribution of these particles to the control of the SMAD2/3 and calcineurin signaling pathways [240]. Some authors also noticed differences in the expression of individual genes, which are probably the targets of miRNA activity. This situation applies to RAF1, BDNF, SATB1, CDK6, and GABRA1, which have an important function in the pathogenesis of glioblastoma $[87,284,306-308]$. Similar observations were noted by Liang et al. in their study regarding the levels of miR-137 and miR-6500-3p in pediatric high-grade glioma cell lines. The authors noted that these particles exhibit anti-tumor activity by negatively affecting the expression of the KIF14, NCAPG and CENPE genes [174]. Earlier observations pointed out the role of KIF14 in promoting the development of other cancers such as breast, ovarian, lung as well as gliomas in the adult population [309-312]. Disturbances in NCAPG expression have been reported in leukemia and melanoma [313]. In addition, the role of the CENEPE gene was suggested in the pathogenesis of hepatocellular carcinoma (HCC) and breast cancer [314,315]. Giunti et al., in their work, indicated that the target of the aforementioned miRNAs were also genes that affect the pathogenesis of glioblastoma. The authors included GRIA1, SORL1, NUCKS1, SOX11, SAP30L, HTT, PXMP4, THRB, PSD3, SPN, AGPAT4, USP31, GRIK3, POM121L8P, TNRC6B, SNX29, HIPK2 and RIMKLA [172]. This shows the complexity of the relationship that governs the pathophysiology of the cancer process, and the special and multi-stage role that miRNA particles play. A thorough knowledge of different relationships will require a series of further studies. 


\section{Conclusions}

Despite the continuous development of modern medicine, high-grade glioma still remains a serious problem, taking the lives of many patients every year. This is due to the complexity of their pathophysiology affecting the poor results of standard treatment. The research conducted in recent years on this group of tumors has shown the important role of miRNA in the course of gliomagenesis; however, lots of the miRNAs mentioned in this review are not specific to glioblastoma and are described in different pathologies.

These particles seem to participate in many stages of the development of the cancer process, such as proliferation, angiogenesis and the regulation of apoptosis. A thorough knowledge of the nature of miRNAs may be helpful in finding new, more effective forms of treatment and improving existing ones. This also applies to the pediatric population, in which much less is known about the nature of high-grade glioma in comparison to adult patients. A full understanding of the regulatory pathways of tumor cell metabolism may enable the development of new and more effective treatments for children with high grade gliomas, including miRNAs.

Conflicts of Interest: The authors declare no conflict of interest.

\section{References}

1. Banelli, B.; Forlani, A.; Allemanni, G.; Morabito, A.; Pistillo, M.P.; Romani, M. MicroRNA in Glioblastoma: An Overview. Int. J. Genom. 2017, 2017, 7639084. [CrossRef] [PubMed]

2. Crocetti, E.; Trama, A.; Stiller, C.; Caldarella, A.; Soffietti, R.; Jaal, J.; Weber, D.C.; Ricardi, U.; Slowinski, J.; Brandes, A. Epidemiology of glial and non-glial brain tumours in Europe. Eur. J. Cancer 2012, 48, 1532-1542. [CrossRef] [PubMed]

3. Ohgaki, H.; Kleihues, P. Population-based studies on incidence, survival rates, and genetic alterations in astrocytic and oligodendroglial gliomas. J. Neuropathol. Exp. Neurol. 2005, 64, 479-489. [CrossRef] [PubMed]

4. Ostrom, Q.T.; Gittleman, H.; Liao, P.; Rouse, C.; Chen, Y.; Dowling, J.; Wolinsky, Y.; Kruchko, C.; Barnholtz-Sloan, J. CBTRUS statistical report: Primary brain and central nervous system tumors diagnosed in the United States in 2007-2011. Neuro. Oncol. 2014, 16 (Suppl. 4), 1-63. [CrossRef] [PubMed]

5. Romani, M.; Pistillo, M.P.; Banelli, B. Epigenetic Targeting of Glioblastoma. Front. Oncol. 2018, 8, 448. [CrossRef] [PubMed]

6. Stupp, R.; Mason, W.P.; Van Den Bent, M.J.; Weller, M.; Fisher, B.; Taphoorn, M.J.; Belanger, K.; Brandes, A.A.; Marosi, C.; Bogdahn, U.; et al. Radiotherapy plus concomitant and adjuvant temozolomide for glioblastoma. N. Engl. J. Med. 2005, 352, 987-996. [CrossRef]

7. De Sanctis, V.; Mazzarella, G.; Osti, M.F.; Valeriani, M.; Alfo, M.; Salvati, M.; Banelli, E.; Tombolini, V.; Enrici, R.M. Radiotherapy and sequential temozolomide compared with radiotherapy with concomitant and sequential temozolomide in the treatment of newly diagnosed glioblastoma multiforme. Anti-Cancer Drugs 2006, 17, 969-975. [CrossRef]

8. Ohgaki, H.; Dessen, P.; Jourde, B.; Horstmann, S.; Nishikawa, T.; Di Patre, P.L.; Burkhard, C.; Schüler, D.; Probst-Hensch, N.M.; Maiorka, P.C.; et al. Genetic pathways to glioblastoma: A population-based study. Cancer Res. 2004, 64, 6892-6899. [CrossRef]

9. Stupp, R.; Hegi, M.E.; Mason, W.P.; van den Bent, M.J.; Taphoorn, M.J.; Janzer, R.C.; Ludwin, S.K.; Allgeier, A.; Fisher, B.; Belanger, K. Effects of radiotherapy with concomitant and adjuvant temozolomide versus radiotherapy alone on survival in glioblastoma in a randomised phase III study: 5-year analysis of the EORTC-NCIC trial. Lancet Oncol. 2009, 10, 459-466. [CrossRef]

10. Lander, E.S.; Linton, L.M.; Birren, B.; Nusbaum, C.; Zody, M.C.; Baldwin, J.; Devon, K.; Dewar, K.; Doyle, M.; FitzHugh, W.; et al. Initial sequencing and analysis of the human genome. Nature 2001, 409, 860-921.

11. Zhang, Y.; Yang, P.; Sun, T.; Li, D.; Xu, X.; Rui, Y.; Li, C.; Chong, M.; Ibrahim, T.; Mercatali, L.; et al. miR-126 and miR-126 repress recruitment of mesenchymal stem cells and inflammatory monocytes to inhibit breast cancer metastasis. Nat. Cell. Biol. 2013, 15, 284-294. [CrossRef] [PubMed]

12. Ambros, V. The functions of animal microRNAs. Nature 2004, 431, 350-355. [CrossRef] [PubMed]

13. Bartel, D.P. MicroRNAs: Genomics, biogenesis, mechanism, and function. Cell 2004, 116, 281-297. [CrossRef] 
14. Bartel, D.P. Metazoan MicroRNAs. Cell 2018, 173, 20-51. [CrossRef] [PubMed]

15. Lee, Y.; Kim, M.; Han, J.; Yeom, K.H.; Lee, S.; Baek, S.H.; Kim, V.N. MicroRNA genes are transcribed by RNA polymerase II. EMBO J. 2004, 23, 4051-4060. [CrossRef] [PubMed]

16. Zhou, X.; Ruan, J.; Wang, G.; Zhang, W. Characterization and identification of microRNA core promoters in four model species. PLoS Comput. Biol. 2007, 3, e37. [CrossRef] [PubMed]

17. Fromm, B.; Billipp, T.; Peck, L.E.; Johansen, M.; Tarver, J.E.; King, B.L.; Newcomb, J.M.; Sempere, L.F.; Flatmark, K.; Hovig, E. A Uniform System for the Annotation of Vertebrate microRNA Genes and the Evolution of the Human microRNAome. Annu. Rev. Genet. 2015, 49, 213-242. [CrossRef]

18. Griffiths-Jones, S. The microRNA Registry. Nucleic Acids Res. 2004, 32, D109-D111. [CrossRef]

19. Lewis, B.P.; Burge, C.B.; Bartel, D.P. Conserved seed pairing, often flanked by adenosines, indicates that thousands of human genes are microRNA targets. Cell 2005, 120, 15-20. [CrossRef]

20. González-Gómez, P.; Sánchez, P.; Mira, H. MicroRNAs as regulators of neural stem cell-related pathways in glioblastoma multiforme. Mol. Neurobiol. 2011, 44, 235-249. [CrossRef]

21. Berindan-Neagoe, I.; Monroig Pdel, C.; Pasculli, B.; Calin, G.A. MicroRNAome genome: A treasure for cancer diagnosis and therapy. CA Cancer J. Clin. 2014, 64, 311-336. [CrossRef] [PubMed]

22. Calin, G.A.; Sevignani, C.; Dumitru, C.D.; Hyslop, T.; Noch, E.; Yendamuri, S.; Shimizu, M.; Rattan, S.; Bullrich, F.; Negrini, M.; et al. Human microRNA genes are frequently located at fragile sites and genomic regions involved in cancers. Proc. Natl. Acad. Sci. USA 2014, 101, 2999-3004. [CrossRef] [PubMed]

23. Hummel, R.; Maurer, J.; Haier, J. MicroRNAs in brain tumors: A new diagnostic and therapeutic perspective? Mol. Neurobiol. 2011, 44, 223-234. [CrossRef] [PubMed]

24. Vella, M.C.; Choi, E.Y.; Lin, S.Y.; Reinert, K.; Slack, F.J. The C. elegans microRNA let-7 binds to imperfect let-7 complementary sites from the lin-41 3'UTR. Genes Dev. 2004, 18, 132-137. [CrossRef] [PubMed]

25. Kawamata, T.; Yoda, M.; Tomari, Y. Multilayer checkpoints for microRNA authenticity during RISC assembly. EMBO Rep. 2011, 12, 944-949. [CrossRef] [PubMed]

26. Shea, A.; Harish, V.; Afzal, Z.; Chijioke, J.; Kedir, H.; Dusmatova, S.; Roy, A.; Ramalinga, M.; Harris, B.; Blancato, J.; et al. MicroRNAs in glioblastoma multiforme pathogenesis and therapeutics. Cancer Med. 2016, 5, 1917-1946. [CrossRef] [PubMed]

27. Møller, H.G.; Rasmussen, A.P.; Andersen, H.H.; Johnsen, K.B.; Henriksen, M.; Duroux, M. A systematic review of microRNA in glioblastoma multiforme: Micro-modulators in the mesenchymal mode of migration and invasion. Mol. Neurobiol. 2013, 47, 131-144. [CrossRef]

28. Ahir, B.K.; Ozer, H.; Engelhard, H.H.; Lakka, S.S. MicroRNAs in glioblastoma pathogenesis and therapy: A comprehensive review. Crit. Rev. Oncol. Hematol. 2017, 120, 22-33. [CrossRef]

29. Godlewski, J.; Nowicki, M.O.; Bronisz, A.; Williams, S.; Otsuki, A.; Nuovo, G.; Raychaudhury, A.; Newton, H.B.; Chiocca, E.A.; Lawler, S. Targeting of the Bmi-1 oncogene/stem cell renewal factor by microRNA-128 inhibits glioma proliferation and self-renewal. Cancer Res. 2008, 68, 9125-9130. [CrossRef]

30. Lawler, S.; Chiocca, E.A. Emerging functions of microRNAs in glioblastoma. J. Neurooncol. 2009, 92, $297-306$. [CrossRef]

31. Silber, J.; Lim, D.A.; Petritsch, C.; Persson, A.I.; Maunakea, A.K.; Yu, M.; Vandenberg, S.R.; Ginzinger, D.G.; James, C.D.; Costello, J.F.; et al. miR-124 and miR-137 inhibit proliferation of glioblastoma multiforme cells and induce differentiation of brain tumor stem cells. BMC Med. 2008, 6, 14. [CrossRef] [PubMed]

32. Li, J.; Zhang, P.; Hui, N. MiR-218 impairs tumor growth and increases chemo-sensitivity to cisplatin in cervical cancer. International journal of molecular sciences. Int. J. Mol. Sci. 2012, 13, 16053-16064. [CrossRef] [PubMed]

33. Ciafrè, S.A.; Galardi, S.; Mangiola, A.; Ferracin, M.; Liu, C.G.; Sabatino, G.; Negrini, M.; Maira, G.; Croce, C.M.; Farace, M.G. Extensive modulation of a set of microRNAs in primary glioblastoma. Biochem. Biophys. Res. Commun. 2005, 334, 1351-1358. [CrossRef] [PubMed]

34. Chan, J.A.; Krichevsky, A.M.; Kosik, K.S. MicroRNA-21 is an antiapoptotic factor in human glioblastoma cells. Cancer Res. 2005, 65, 6029-6033. [CrossRef] [PubMed]

35. Wang, Q.; Li, P.; Li, A.; Jiang, W.; Wang, H.; Wang, J.; Xie, K. Plasma specifc miRNAs as predictive biomarkers for diagnosis and prognosis of glioma. J. Exp. Clin. Cancer Res. 2012, 31, 97. [CrossRef] [PubMed]

36. De Smaele, E.; Ferretti, E.; Gulino, A. MicroRNAs as biomarkers for CNS cancer and other disorders. Brain Res. 2010, 1338, 100-111. [CrossRef] 
37. Yang, G.; Zhang, R.; Chen, X.; Mu, Y.; Ai, J.; Shi, C.; Liu, Y.; Shi, C.; Sun, L.; Rainov, N.G.; et al. MiR-106a inhibits glioma cell growth by targeting E2F1 independent of p53 status. J. Mol. Med. 2011, 89, 1037-1050. [CrossRef]

38. Huse, J.T.; Brennan, C.; Hambardzumyan, D.; Wee, B.; Pena, J.; Rouhanifard, S.H.; Sohn-Lee, C.; le Sage, C.; Agami, R.; Tuschl, T.; et al. The PTEN-regulating microRNA miR-26a is amplified in high-grade glioma and facilitates gliomagenesis in vivo. Genes Dev. 2009, 23, 1327-1337. [CrossRef]

39. Hermansen, S.K.; Dahlrot, R.H.; Nielsen, B.S.; Hansen, S.; Kristensen, B.W. MiR-21 expression in the tumor cell compartment holds unfavourable prognostic value in gliomas. J. Neurooncol. 2013, 111, 71-81. [CrossRef]

40. Corsten, M.F.; Miranda, R.; Kasmieh, R.; Krichevsky, A.M.; Weissleder, R.; Shah, K. MicroRNA-21 knockdown disrupts glioma growth in vivo and displays synergistic cytotoxicity with neural precursor cell delivered S-TRAIL in human gliomas. Cancer Res. 2007, 67, 8994-9000. [CrossRef]

41. Wu, Z.; Sun, L.; Wang, H.; Yao, J.; Jiang, C.; Xu, W.; Yang, Z. MiR-328 expression is decreased in high-grade gliomas and is associated with worse survival in primary glioblastoma. PLoS ONE 2012, 7, e47270. [CrossRef] [PubMed]

42. Jiang, J.; Sun, X.; Wang, W.; Jin, X.; Bo, X.; Li, Z.; Bian, A.; Jiu, J.; Wang, X.; Liu, D.; et al. Tumor microRNA-335 expression is associated with poor prognosis in human glioma. Med. Oncol. 2012, 29, 3472-3477. [CrossRef] [PubMed]

43. Conti, A.; Aguennouz, M.; La Torre, D.; Tomasello, C.; Cardali, S.; Angileri, F.F.; Maio, F.; Cama, A.; Germanò, A.; Vita, G.; et al. miR-21 and 221 upregulation and miR-181b downregulation in human grade II-IV astrocytic tumors. J. Neurooncol. 2009, 93, 325-332. [CrossRef] [PubMed]

44. Kefas, B.; Godlewski, J.; Comeau, L.; Li, Y.; Abounader, R.; Hawkinson, M.; Lee, J.; Fine, H.; Chiocca, E.A.; Lawler, S.; et al. microRNA-7 inhibits the epidermal growth factor receptor and the Akt pathway and is down-regulated in glioblastoma. Cancer Res. 2008, 68, 3566-3572. [CrossRef]

45. Shi, L.; Cheng, Z.; Zhang, J.; Li, R.; Zhao, P.; Fu, Z.; You, Y. hsa-mir-181a and hsa-mir-181b function as tumor suppressors in human glioma cells. Brain Res. 2008, 1236, 185-193. [CrossRef]

46. Kong, D.; Li, Y.; Wang, Z.; Sarkar, F.H. Cancer Stem Cells and Epithelial-to-Mesenchymal Transition (EMT)-Phenotypic Cells: Are They Cousins or Twins? Cancers 2011, 3, 716-729. [CrossRef]

47. Lamouille, S.; Xu, J.; Derynck, R. Molecular mechanisms of epithelial-mesenchymal transition. Nat. Rev. Mol. Cell. Biol. 2014, 15, 178-196. [CrossRef]

48. Kalluri, R.; Weinberg, R.A. The basics of epithelial-mesenchymal transition. J. Clin. Investig. 2009, 119, 1420-1428. [CrossRef]

49. Thiery, J.P.; Sleeman, J.P. Complex networks orchestrate epithelial-mesenchymal transitions. Nat. Rev. Mol. Cell. Biol. 2006, 7, 131-142. [CrossRef]

50. Hanahan, D.; Weinberg, R. Hallmarks of cancer: The next generation. Cell 2011, 144, 646-674. [CrossRef]

51. Harazono, Y.L.; Muramatsu, T.; Endo, H.; Uzawa, N.; Kawano, T.; Harada, K.; Inazawa, J.; Kozaki, K. miR-655 Is an EMT-Suppressive MicroRNA Targeting ZEB1 and TGFBR2. PLoS ONE 2013, 8, e62757. [CrossRef] [PubMed]

52. Gabriely, G.; Wurdinger, T.; Kesari, S.; Esau, C.C.; Burchard, J.; Linsley, P.S.; Krichevsky, A.M. MicroRNA 21 promotes glioma invasion by targeting matrix metalloproteinase regulators. Mol. Cell. Biol. 2008, 28, 5369-5380. [CrossRef] [PubMed]

53. Li, Y.; Wang, Y.; Yu, L.; Sun, C.; Cheng, D.; Yu, S.; Wang, Q.; Yan, Y.; Kang, C.; Jin, S.; et al. miR-146b-5p inhibits glioma migration and invasion by targeting MMP16. Cancer Lett. 2013, 339, 260-269. [CrossRef] [PubMed]

54. Cui, B.; Li, B.; Liu, Q.; Cui, Y. lncRNA CCAT1 Promotes Glioma Tumorigenesis by Sponging miR-181b. J. Cell. Biochem. 2017, 118, 4548-4557. [CrossRef]

55. Sun, L.; Yan, W.; Wang, Y.; Sun, G.; Luo, H.; Zhang, J.; Wang, X.; You, Y.; Yang, Z.; Liu, N. MicroRNA-10b induces glioma cell invasion by modulating MMP-14 and uPAR expression via HOXD10. Brain Res. 2011, 1389, 9-18. [CrossRef] [PubMed]

56. Wu, D.G.; Wang, Y.Y.; Fan, L.G.; Luo, H.; Han, B.; Sun, L.H.; Wang, X.F.; Zhang, J.X.; Cao, L.; Wang, X.R.; et al. MicroRNA-7 regulates glioblastoma cell invasion via targeting focal adhesion kinase expression. Chin. Med. J. 2011, 124, 2616-2621.

57. Lin, J.S.; Teo, D.H.; Lam, K.; Jeyaseelan, K.; Wang, S. MicroRNA-10b pleiotropically regulates invasion, angiogenicity and apoptosis of tumor cells resembling mesenchymal subtype of glioblastoma multiforme. Cell Death Dis. 2012, 3, e398. [CrossRef] 
58. Liao, H.; Bai, Y.; Qiu, S.; Zheng, L.; Huang, L.; Liu, T.; Wang, X.; Liu, Y.; Xu, N.; Yan, X.; et al. MiR-203 downregulation is responsible for chemoresistance in human glioblastoma by promoting epithelial-mesenchymal transition via SNAI2. Oncotarget 2015, 6, 8914-8928. [CrossRef]

59. Carlson, B.M. Human Embryology and Developmental Biology, 5th ed.; Elsevier Health Sciences: Philadelphia, PA, USA, 2013; pp. 101-102, 106, 313, 362, 382.

60. Nieto, M.A. The snail superfamily of zinc-finger transcription factors. Nat. Rev. Mol. Cell. Biol. 2012, 3, 155-166. [CrossRef]

61. Inukai, T.; Inoue, A.; Kurosawa, H.; Goi, K.; Shinjyo, T.; Ozawa, K.; Mao, M.; Inaba, T.; Look, A.T. SLUG, a ces-1-related zinc finger transcription factor gene with antiapoptotic activity, is a downstream target of the E2A-HLF oncoprotein. Mol. Cell 1999, 4, 343-352. [CrossRef]

62. Chang, T.H.; Tsai, M.F.; Su, K.Y.; Wu, S.G.; Huang, C.P.; Yu, S.L.; Yu, Y.L.; Lan, C.C.; Yang, C.H.; Lin, S.B.; et al. Slug confers resistance to the epidermal growth factor receptor tyrosine kinase inhibitor. Am. J. Respir. Crit. Care Med. 2011, 183, 1071-1079. [CrossRef] [PubMed]

63. Shih, J.Y.; Yang, P.C. The EMT regulator slug and lung carcinogenesis. Carcinogenesis 2011, 32, $1299-1304$. [CrossRef] [PubMed]

64. Chang, C.; Chao, C.; Xia, W.; Yang, J.; Xiong, Y.; Li, C.; Yu, W.; Rehman, S.K.; Hsu, J.L.; Lee, H.; et al. p53 regulates epithelial-mesenchymal transition (EMT) and stem cell properties through modulating miRNAs. Nat. Cell Biol. 2011, 13, 317-323. [CrossRef] [PubMed]

65. Snoek-van Beurden, P.A.M.; Von den Hoff, J.W. Zymographic techniques for the analysis of matrix metalloproteinases and their inhibitors. Biotechniques 2015, 38, 73-83. [CrossRef]

66. Verma, R.P.; Hansch, C. Matrix metalloproteinases (MMPs): Chemical-biological functions and (Q)SARs. Bioorg. Med. Chem. 2007, 15, 2223-2268. [CrossRef]

67. Ellerbroek, S.M.; Halbleib, J.M.; Benavidez, M.; Warmka, J.K.; Wattenberg, E.V.; Stack, M.S.; Hudson, L.G. Phosphatidylinositol 3-kinase activity in epidermal growth factor-stimulated matrix metalloprotein-ase-9 production and cell surface association. Cancer Res. 2001, 61, 1855-1861.

68. Kesanakurti, D.; Chetty, C.; Maddirela, D.R.; Gujrati, M.; Rao, J.S. Functional cooperativity by direct interaction between PAK4 and MMP-2 in the regulation of anoikis resistance, migration and invasion in glioma. Cell Death Dis. 2012, 3, e445. [CrossRef]

69. Litak, J.; Mazurek, M.; Grochowski, C.; Kamieniak, P.; Roliński, J. PD-L1/PD-1 Axis in Glioblastoma Multiforme. Int. J. Mol. Sci. 2019, 20, 5347. [CrossRef]

70. Choe, G.; Park, J.K.; Jouben-Steele, L.; Kremen, T.J.; Liau, L.M.; Vinters, H.V.; Cloughesy, T.F.; Mischel, P.S. Active matrix metalloproteinase 9 expression is associated with primary glioblastoma subtype. Clin. Cancer Res. 2002, 8, 2894-2901.

71. Anand, M.; Van Meter, T.E.; Fillmore, H.L. Epidermal growth factor induces matrix metalloproteinase-1 (MMP-1) expression and invasion in glioma cell lines via the MAPK pathway. J. Neuro Oncol. 2011, 104, 679-687. [CrossRef]

72. Papagiannakopoulos, T.; Shapiro, A.; Kosik, K.S. MicroRNA-21 targets a network of key tumor-suppressive pathways in glioblastoma cells. Cancer Res. 2008, 68, 8164-8172. [CrossRef] [PubMed]

73. Schramedei, K.; Mörbt, N.; Pfeifer, G.; Läuter, J.; Rosolowski, M.; Tomm, J.M.; von Bergen, M.; Horn, F.; Brocke-Heidrich, K. MicroRNA-21 targets tumor suppressor genes ANP32A and SMARCA4. Oncogene 2011, 30, 2975-2985. [CrossRef]

74. Kwak, H.J.; Kim, Y.J.; Chun, K.R.; Woo, Y.M.; Park, S.J.; Jeong, J.A.; Jo, S.H.; Kim, T.H.; Min, H.S.; Chae, J.S.; et al. Downregulation of Spry2 by miR-21 triggers malignancy in human gliomas. Oncogene 2011, 30, 2433-2442. [CrossRef] [PubMed]

75. Zhang, C.; Li, C.; Li, J.; Han, J.; Shang, D.; Zhang, Y.; Zhang, W.; Yao, Q.; Han, L.; Xu, Y.; et al. Identification of miRNA-mediated core gene module for glioma patient prediction by integrating high-throughput miRNA, mRNA expression and pathway structure. PLoS ONE 2014, 9, e96908. [CrossRef] [PubMed]

76. Chou, C.K.; Chen, R.F.; Chou, F.F.; Chang, H.W.; Chen, Y.J.; Lee, Y.F.; Yang, K.D.; Cheng, J.T.; Huang, C.C.; Liu, R.T. miR-146b is highly expressed in adult papillary thyroid carcinomas with high risk features including extrathyroidal invasion and the BRAF(V600E) mutation. Thyroid 2010, 20, 489-494. [CrossRef] [PubMed]

77. Hurst, D.R.; Edmonds, M.D.; Scott, G.K.; Benz, C.C.; Vaidya, K.S.; Welch, D.R. Breast cancer metastasis suppressor 1 up-regulates miR-146, which suppresses breast cancer metastasis. Cancer Res. 2009, 69, 1279-1283. [CrossRef] 
78. Xia, H.; Qi, Y.; Ng, S.S.; Chen, X.; Li, D.; Chen, S.; Ge, R.; Jiang, S.; Li, G.; Chen, Y.; et al. microRNA-146b inhibits glioma cell migration and invasion by targeting MMPs. Brain Res. 2009, 1269, 158-165. [CrossRef]

79. Zheng, J.; Liu, X.; Wang, P.; Xue, Y.; Ma, J.; Qu, C.; Liu, Y. CRNDE Promotes Malignant Progression of Glioma by Attenuating miR-384/PIWIL4/STAT3 Axis. Mol. Ther. J. Am. Soc. Gene Ther. 2016, 24, 1199-1215. [CrossRef]

80. Liu, X.; Wang, S.; Yuan, A.; Yuan, X.; Liu, B. MicroRNA-140 represses glioma growth and metastasis by directly targeting ADAM9. Oncol. Rep. 2016, 36, 2329-2338. [CrossRef]

81. Asuthkar, S.; Velpula, K.K.; Chetty, C.; Gorantla, B.; Rao, J.S. Epigenetic regulation of miRNA-211 by MMP-9 governs glioma cell apoptosis, chemosensitivity and radiosensitivity. Oncotarget 2012, 3, 1439-1454. [CrossRef]

82. Hu, Y.; Li, Y.; Wu, C.; Zhou, L.; Han, X.; Wang, Q.; Xie, X.; Zhou, Y.; Du, Z. MicroRNA-140-5p inhibits cell proliferation and invasion by regulating VEGFA/MMP2 signaling in glioma. Tumour Biol. J. Int. Soc. Oncodev. Biol. Med. 2017, 39, 1010428317697558. [CrossRef] [PubMed]

83. Zheng, X.; Chopp, M.; Lu, Y.; Buller, B.; Jiang, F. MiR-15b and miR-152 reduce glioma cell invasion and angiogenesis via NRP-2 and MMP-3. Cancer Lett. 2013, 329, 146-154. [CrossRef]

84. Chen, L.; Chen, X.R.; Chen, F.F.; Liu, Y.; Li, P.; Zhang, R.; Yan, K.; Yi, Y.J.; Xu, Z.M.; Jiang, X.D. MicroRNA-107 inhibits U87 glioma stem cells growth and invasion. Cell. Mol. Neurobiol. 2013, 33, 651-657. [CrossRef]

85. Chen, L.; Chen, X.R.; Zhang, R.; Li, P.; Liu, Y.; Yan, K.; Jiang, X.D. MicroRNA-107 inhibits glioma cell migration and invasion by modulating Notch2 expression. J. Neuro Oncol. 2013, 112, 59-66. [CrossRef] [PubMed]

86. Wang, W.; Dai, L.X.; Zhang, S.; Yang, Y.; Yan, N.; Fan, P.; Dai, L.; Tian, H.W.; Cheng, L.; Zhang, X.M.; et al. Regulation of epidermal growth factor receptor signaling by plasmid-based microRNA-7 inhibits human malignant gliomas growth and metastasis in vivo. Neoplasma 2013, 60, 274-283. [CrossRef] [PubMed]

87. Liu, Z.; Liu, Y.; Li, L.; Xu, Z.; Bi, B.; Wang, Y.; Li, J.Y. MiR-7-5p is frequently downregulated in glioblastoma microvasculature and inhibits vascular endothelial cell proliferation by targeting raf1. Tumor Biol. 2014, 35, 10177-10184. [CrossRef]

88. Lu, Z.J.; Liu, S.Y.; Yao, Y.Q.; Zhou, Y.J.; Zhang, S.; Dai, L.; Tian, H.W.; Zhou, Y.; Deng, H.X.; Yang, J.L.; et al. The effect of miR-7 on behavior and global protein expression in glioma cell lines. Electrophoresis 2011, 32, 3612-3620. [CrossRef]

89. Herbst, R.S. Review of epidermal growth factor receptor biology. Int. J. Radiat. Oncol. Biol. Phys. 2004, 59 (Suppl. 2), 21-26. [CrossRef]

90. Oda, K.; Matsuoka, Y.; Funahashi, A.; Kitano, H. A comprehensive pathway map of epidermal growth factor receptor signaling. Mol. Syst. Biol. 2005, 1, E1-E17. [CrossRef]

91. Lynch, T.J.; Bell, D.W.; Sordella, R.; Gurubhagavatula, S.; Okimoto, R.A.; Brannigan, B.W.; Harris, P.L.; Haserlat, S.M.; Supko, J.G.; Haluska, F.G.; et al. Activating mutations in the epidermal growth factor receptor underlying responsiveness of non-small-cell lung cancer to gefitinib (PDF). N. Engl. J. Med. 2004, 350, 2129-2139. [CrossRef]

92. Watanabe, K.; Tachibana, O.; Sata, K.; Yonekawa, Y.; Kleihues, P.; Ohgaki, H. Overexpression of the EGF receptor and p53 mutations are mutually exclusive in the evolution of primary and secondary glioblastomas. Brain Pathol. 1996, 6, 217-223. [CrossRef]

93. Kuan, C.T.; Wikstrand, C.J.; Bigner, D.D. EGF mutant receptor vIII as a molecular target in cancer therapy. Endocr. Relat. Cancer 2001, 8, 83-96. [CrossRef]

94. Guillamo, J.-S.; Valable, S.; Marteau, L.; Leuraud, P.; Marie, Y.; Poupon, M.-F.; Parienti, J.-J.; Raymond, E.; Peschanski, M.; De Boüard, S. Molecular Mechanisms Underlying Effects of Epidermal Growth Factor Receptor Inhibition on Invasion, Proliferation, and Angiogenesis in Experimental Glioma. Clin. Cancer Res. 2009, 15, 3697-3704. [CrossRef]

95. Huang, P.H.; Mukasa, A.; Bonavia, R.; Flynn, R.A.; Brewer, Z.E.; Cavenee, W.K.; Furnari, F.B.; White, F.M. Quantitative analysis of EGFRvIII cellular signaling networks reveals a combinatorial therapeutic strategy for glioblastoma. Proc. Natl. Acad. Sci. USA 2007, 104, 12867-12872. [CrossRef] [PubMed]

96. Bonavia, R.; Inda, M.; Vandenberg, S.; Cheng, S.; Nagane, M.; Hadwiger, P.; Tan, P.; Sah, D.; Cavenee, W.; Furnari, F. EGFRvIII promotes glioma angiogenesis and growth through the NF- $\mathrm{kB}$, interleukin-8 pathway. Oncogene 2012, 31, 4054-4066. [CrossRef] [PubMed] 
97. Shibata, T.; Kawano, T.; Nagayasu, H.; Okumura, K.; Arisue, M.; Hamada, J.-I.; Takeichi, N.; Hosokawa, M. Enhancing effects of epidermal growth factor on human squamous cell carcinoma motility and matrix degradation but not growth. Tumor Boil. 1996, 17, 168-175. [CrossRef] [PubMed]

98. Price, J.; Wilson, H.; Haites, N. Epidermal growth factor (EGF) Increases the in vitro invasion, motility and adhesion interactions of the primary renal carcinoma cell line, A704. Eur. J. Cancer 1996, 32, 1977-1982. [CrossRef]

99. Surget, S.; Khoury, M.P.; Bourdon, J.C. Uncovering the role of p53 splice variants in human malignancy: A clinical perspective. Onco Targets Ther. 2013, 7, 57-68. [CrossRef]

100. Stiewe, T. The p53 family in differentiation and tumorigenesis. Nat. Rev. Cancer 2007, 7, 165-167. [CrossRef]

101. Lin, L.; Ozaki, T.; Takada, Y.; Kageyama, H.; Nakamura, Y.; Hata, A.; Zhang, J.H.; Simonds, W.F.; Nakagawara, A.; Koseki, H. topors, a p53 and topoisomerase I-binding RING finger protein, is a coactivator of p53 in growth suppression induced by DNA damage. Oncogene 2005, 24, 3385-3396. [CrossRef]

102. Li, Q.; Wang, X.; Wu, X.; Rui, Y.; Liu, W.; Wang, J.; Wang, X.; Liou, Y.C.; Ye, Z.; Lin, S.C. Daxx Cooperates with the Axin/HIPK2/p53 complex to induce cell death. Cancer Res. 2007, 67, 66-74. [CrossRef] [PubMed]

103. Moumen, A.; Masterson, P.; O'Connor, M.J.; Jackson, S.P. hnRNP K: An HDM2 target and transcriptional coactivator of p53 in response to DNA damage. Cell 2005, 123, 1065-1078. [CrossRef] [PubMed]

104. Coutts, A.S.; La Thangue, N.B. The p53 response: Emerging levels of co-factor complexity. Biochem. Biophys. Res. Commun. 2005, 331, 778-785. [CrossRef] [PubMed]

105. Bullock, A.N.; Fersht, A.R. Rescuing the function of mutant p53. Nat. Rev. Cancer 2001, 1, 68-76. [CrossRef]

106. Galluzzi, L.; López-Soto, A.; Kumar, S.; Kroemer, G. Caspases Connect Cell-Death Signaling to Organismal Homeostasis. Immunity 2016, 44, 221-231. [CrossRef]

107. Zhou, X.; Zhang, J.; Jia, Q.; Ren, Y.; Wang, Y.; Shi, L.; Liu, N.; Wang, G.; Pu, P.; You, Y.; et al. Reduction of miR-21 induces glioma cell apoptosis via activating caspase 9 and 3. Oncol. Rep. 2010, 24, 195-201.

108. Kouri, F.M.; Ritner, C.; Stegh, A.H. miRNA-182 and the regulation of the glioblastoma phenotype-Toward miRNA-based precision therapeutics. Cell Cycle 2015, 14, 3794-3800. [CrossRef]

109. Zheng, J.; Li, X.D.; Wang, P.; Liu, X.B.; Xue, Y.X.; Hu, Y.; Li, Z.; Li, Z.Q.; Wang, Z.H.; Liu, Y.H. CRNDE affects the malignant biological characteristics of human glioma stem cells by negatively regulating miR-186. Oncotarget 2015, 6, 25339-25355. [CrossRef]

110. He, J.; Zhang, W.; Zhou, Q.; Zhao, T.; Song, Y.; Chai, L.; Li, Y. Low-expression of microRNA-107 inhibits cell apoptosis in glioma by upregulation of SALL4. Int. J. Biochem. Cell Biol. 2013, 45, 1962-1973.

111. Nakano, K.; Vousden, K.H. PUMA, a novel proapoptotic gene, is induced by p53. Mol. Cell 2001, 7, $683-694$. [CrossRef]

112. Zhao, Y.; Coloff, J.L.; Ferguson, E.C.; Jacobs, S.R.; Cui, K.; Rathmell, J.C. Glucose metabolism attenuates p53 and Puma-dependent cell death upon growth factor deprivation. J. Biol. Chem. 2008, 283, 36344-36353. [CrossRef] [PubMed]

113. Zhang, C.; Zhang, J.; Zhang, A.-L.; Shi, Z.; Han, L.; Jia, Z.; Yang, W.-D.; Wang, G.-X.; Jiang, T.; You, Y.; et al. MiR-221 and miR-222 target PUMA to induce cell survival in glioblastoma. Mol. Cancer 2010, 9, 229. [CrossRef] [PubMed]

114. Chen, L.; Zhang, J.; Han, L.; Zhang, A.; Zhang, C.; Zheng, Y.; Jiang, T.; Pu, P.; Jiang, C.; Kang, C. Downregulation of miR-221/222 sensitizes glioma cells to temozolomide by regulating apoptosis independently of p53 status. Oncol. Rep. 2012, 27, 854-860. [PubMed]

115. Shu, M.; Zheng, X.; Wu, S.; Lu, H.; Leng, T.; Zhu, W.; Zhou, Y.; Ou, Y.; Lin, X.; Lin, Y.; et al. Targeting oncogenic miR-335 inhibits growth and invasion of malignant astrocytoma cells. Mol. Cancer 2011, 10, 59. [CrossRef]

116. Comincini, S.; Allavena, G.; Palumbo, S.; Morini, M.; Durando, F.; Angeletti, F.; Pirtoli, L.; Miracco, C. microRNA-17 regulates the expression of ATG7 and modulates the autophagy process, improving the sensitivity to temozolomide and low-dose ionizing radiation treatments in human glioblastoma cells. Cancer Biol. Ther. 2013, 14, 574-586. [CrossRef]

117. Grochowski, C.; Staśkiewicz, G. Ultra high field TOF-MRA: A method to visualize small cerebral vessels. 7 T TOF-MRA sequence parameters on different MRI scanners-Literature review. Neurol. Neurochir. Pol. 2017, 51, 411-418. [CrossRef]

118. Krishnan, S.; Szabo, E.; Burghardt, I.; Frei, K.; Tabatabai, G.; Weller, M. Modulation of cerebral endothe-lial cell function by TGF- $\beta$ in glioblastoma: VEGF-dependent angiogenesis versus endothelial mesenchy-mal transition. Oncotarget 2015, 6, 22480-22495. [CrossRef] 
119. Keller, S.; Schmidt, M.H.H. EGFR and EGFRvIII Promote Angiogenesis and Cell Invasion in Glioblasto-ma: Combination Therapies for an Effective Treatment. Int. J. Mol. Sci. 2017, 18, 1295. [CrossRef]

120. Hardee, M.E.; Zagzag, D. Mechanisms of glioma-associated neovascularization. Am. J. Pathol. 2012, 181, 1126-1141. [CrossRef]

121. Wang, S.; Olson, E.N. AngiomiRs-Key regulators of angiogenesis. Curr. Opin. Genet Dev. 2009, $19,205-211$. [CrossRef]

122. Kaur, B.; Khwaja, F.W.; Severson, E.A.; Matheny, S.L.; Brat, D.J.; Van Meir, E.G. Hypoxia and the hy-poxia-inducible-factor pathway in glioma growth and angiogenesis. Neuro Oncol. 2005, 7, 134-153. [CrossRef]

123. Weathers, S.P.; de Groot, J. VEGF Manipulation in Glioblastoma. Oncology 2015, 29, 720-727.

124. Shimizu, A.; Nakayama, H.; Wang, P.; Konig, C.; Akino, T.; Sandlund, J.; Coma, S.; Italiano, J.E., Jr.; Mammoto, A.; Bielenberg, D.R.; et al. Netrin-1 promotes glioblastoma cell invasiveness and angiogenesis by multiple pathways including activation of RhoA, cathepsin B, and cAMP-response element-binding protein. J. Biol. Chem. 2013, 288, 2210-2222. [CrossRef] [PubMed]

125. Jain, R.K.; di Tomaso, E.; Duda, D.G.; Loeffler, J.S.; Sorensen, A.G.; Batchelor, T.T. Angiogenesis in brain tumours. Nat. Rev. Neurosci. 2007, 8, 610-622. [CrossRef] [PubMed]

126. Knizhnik, A.V.; Roos, W.P.; Nikolova, T.; Quiros, S.; Tomaszowski, K.H.; Christmann, M.; Kaina, B. Survival and death strategies in glioma cells: Autophagy, senescence and apoptosis triggered by a single type of temozolomide-induced DNA damage. PLoS ONE 2013, 8, e55665. [CrossRef] [PubMed]

127. Mazurek, M.; Litak, J.; Kamieniak, P.; Kulesza, B.; Jonak, K.; Baj, J.; Grochowski, C. Metformin as Potential Therapy for High-Grade Glioma. Cancers 2020, 12, 210. [CrossRef]

128. Wilkins, S.E.; Abboud, M.I.; Hancock, R.L.; Schofield, C.J. Targeting Protein-Protein Interactions in the HIF System. ChemMedChem 2016, 11, 773-786. [CrossRef]

129. Smith, T.G.; Robbins, P.A.; Ratcliffe, P.J. The human side of hypoxia-inducible factor. Br. J. Haematol. 2008, 141, 325-334. [CrossRef]

130. Huang, W.J.; Chen, W.W.; Zhang, X. Glioblastoma multiforme: Effect of hypoxia and hypoxia inducible factors on therapeutic approaches. Oncol. Lett. 2016, 12, 2283-2288. [CrossRef]

131. Iwadate, Y. Epithelial-mesenchymal transition in glioblastoma progression. Oncol. Lett. 2016, 11, 1615-1620. [CrossRef]

132. Fischbach, C.; Kong, H.J.; Hsiong, S.X.; Evangelista, M.B.; Yuen, W.; Mooney, D.J. Cancer cell angiogenic capability is regulated by 3D culture and integrin engagement. Proc. Natl. Acad. Sci. USA 2009, 106, 399-404. [CrossRef] [PubMed]

133. Hermansen, S.K.; Nielsen, B.S.; Aaberg-Jessen, C.; Kristensen, B.W. miR-21 Is Linked to Glioma Angiogenesis: A Co-Localization Study. J. Histochem. Cytochem. 2016, 64, 138-148. [CrossRef] [PubMed]

134. Shi, Z.M.; Wang, J.; Yan, Z.; You, Y.P.; Li, C.Y.; Qian, X.; Yin, Y.; Zhao, P.; Wang, Y.Y.; Wang, X.F.; et al. MiR-128 inhibits tumor growth and angiogenesis by targeting p70S6K1. PLoS ONE 2012, 7, e32709. [CrossRef] [PubMed]

135. Wang, L.; Shi, Z.M.; Jiang, C.F.; Liu, X.; Chen, Q.D.; Qian, X.; Li, D.M.; Ge, X.; Wang, X.F.; Liu, L.Z.; et al. MiR-143 acts as a tumor suppressor by targeting N-RAS and enhances temozolomideinduced apoptosis in glioma. Oncotarget 2014, 5, 5416-5427. [CrossRef]

136. Agrawal, R.; Pandey, P.; Jha, P.; Dwivedi, V.; Sarkar, C.; Kulshreshtha, R. Hypoxic signature of microRNAs in glioblastoma: Insights from small RNA deep sequencing. BMC Genom. 2014, 15, 686. [CrossRef]

137. Wurdinger, T.; Tannous, B.A.; Saydam, O.; Skog, J.; Grau, S.; Soutschek, J.; Weissleder, R.; Breakefield, X.O.; Krichevsky, A.M. miR-296 regulates growth factor receptor overexpression in angiogenic endothelial cells. Cancer Cell 2008, 14, 382-393. [CrossRef]

138. Smits, M.; Wurdinger, T.; van het Hof, B.; Drexhage, J.A.; Geerts, D.; Wesseling, P.; Noske, D.P.; Vandertop, W.P.; de Vries, H.E.; Reijerkerk, A. Mycassociated zinc fnger protein (MAZ) is regulated by miR-125b and mediates VEGF-induced angiogenesis in glioblastoma. FASEB J. 2012, 26, 2639-2647. [CrossRef]

139. Ma, Y.; Xue, Y.; Liu, X.; Qu, C.; Cai, H.; Wang, P.; Li, Z.; Li, Z.; Liu, Y. SNHG15 affects the growth of glioma microvascular endothelial cells by negatively regulating miR-153. Oncol. Rep. 2017, 38, 3265-3277. [CrossRef]

140. Chen, L.; Li, Z.Y.; Xu, S.Y.; Zhang, X.J.; Zhang, Y.; Luo, K.; Li, W.P. Upregulation of miR-107 Inhibits Glioma Angiogenesis and VEGF Expression. Cell. Mol. Neurobiol. 2016, 36, 113-120. [CrossRef] 
141. Fang, L.; Deng, Z.; Shatseva, T.; Yang, J.; Peng, C.; Du, W.W.; Yee, A.J.; Ang, L.C.; He, C.; Shan, S.W.; et al. MicroRNA miR-93 promotes tumor growth and angiogenesis by targeting integrin-beta8. Oncogene 2011, 30, 806-821. [CrossRef]

142. Tchaicha, J.H.; Reyes, S.B.; Shin, J.; Hossain, M.G.; Lang, F.F.; McCarty, J.H. Glioblastoma angiogenesis and tumor cell invasiveness are differentially regulated by $\beta 8$ integrin. Cancer Res. 2011, 71, 6371-6381. [CrossRef] [PubMed]

143. Bonauer, A.; Dimmeler, S. The microRNA-17-92 cluster: Still a miRacle? Cell Cycle 2009, 8, 3866-3873. [CrossRef] [PubMed]

144. Jia, P.; Cai, H.; Liu, X.; Chen, J.; Ma, J.; Wang, P.; Liu, Y.; Zheng, J.; Xue, Y. Long non-coding RNA H19 regulates glioma angiogenesis and the biological behavior of glioma-associated endothelial cells by inhibiting microRNA-29a. Cancer Lett. 2016, 381, 359-369. [CrossRef] [PubMed]

145. Tili, E.; Michaille, J.-J.; Wernicke, R.; Alder, H.; Costinean, S.; Volinia, S.; Croce, C.M. Mutator activity induced by microRNA-155 (miR-155) links inflammation and cancer. Proc. Natl. Acad. Sci. USA 2011, 108, 4908-4913. [CrossRef]

146. Ma, Y.; Wang, P.; Xue, Y.; Qu, C.; Zheng, J.; Liu, X.; Ma, J.; Liu, Y. PVT1 affects growth of glioma microvascular endothelial cells by negatively regulating miR-186. Tumor Biol. 2017, 39, 1010428317694326. [CrossRef]

147. Cheng, Z.; Li, Z.; Ma, K.; Li, X.; Tian, N.; Duan, J.; Xiao, X.; Wang, Y. Long Non-coding RNA XIST Promotes Glioma Tumorigenicity and Angiogenesis by Acting as a Molecular Sponge of miR-429. J. Cancer 2017, 8, 4106-4116. [CrossRef]

148. Lo Dico, A.; Costa, V.; Martelli, C.; Diceglie, C.; Rajata, F.; Rizzo, A.; Mancone, C.; Tripodi, M.; Ottobrini, L.; Alessandro, R.; et al. MiR675-5p Acts on HIF-1alpha to Sustain Hypoxic Responses: A New Therapeutic Strategy for Glioma. Theranostics 2016, 6, 1105-1118. [CrossRef]

149. Kyriakis, J.M. The integration of signaling by multiprotein complexes containing Raf kinases. Biochim. Biophys. Acta 2007, 1773, 1238-1247. [CrossRef]

150. Von Kriegsheim, A.; Pitt, A.; Grindlay, G.J.; Kolch, W.; Dhillon, A.S. Regulation of the Raf-MEK-ERK pathway by protein phosphatase 5. Nat. Cell Biol. 2006, 8, 1011-1016. [CrossRef]

151. McPhillips, F.; Mullen, P.; MacLeod, K.; Sewell, J.M.; Monia, B.P.; Cameron, D.A.; Smyth, J.F.; Langdon, S.P. Raf-1 is the predominant Raf isoform that mediates growth factor-stimulated growth in ovarian cancer cells. Carcinogenesis 2005, 27, 729-739. [CrossRef]

152. Fushimi, K.; Nakashima, S.; You, F.; Takigawa, M.; Shimizu, K. Prostaglandin E2 downregulates TNF-alpha-induced production of matrix metalloproteinase-1 in HCS-2/8 chondrocytes by inhibiting Raf-1/MEK/ERK cascade through EP4 prostanoid receptor activation. J. Cell Biochem. 2007, 100, 783-793. [CrossRef]

153. Pal, A.; Ahmad, A.; Khan, S.; Sakabe, I.; Zhang, C.; Kasid, U.N.; Ahmad, I. Systemic delivery of RafsiRNA using cationic cardiolipin liposomes silences Raf-1 expression and inhibits tumor growth in xenograft model of human prostate cancer. Int. J. Oncol. 2005, 26, 1087-1091. [CrossRef] [PubMed]

154. Leicht, D.T.; Balan, V.; Kaplun, A.; Singh-Gupta, V.; Kaplun, L.; Dobson, M.; Tzivion, G. Raf kinases: Function, regulation and role in human cancer. Biochim. Biophys. Acta BBA Bioenerg. 2007, 1773, 1196-1212. [CrossRef] [PubMed]

155. Zebisch, A.; Troppmair, J. Back to the roots: The remarkable RAF oncogene story. Cell Mol. Life Sci. 2006, 63, 1314-1330. [CrossRef] [PubMed]

156. Lyustikman, Y.; Momota, H.; Pao, W.; Holland, E.C. Constitutive activation of Raf-1 induces glioma formation in mice. Neoplasia 2008, 10, 501-510. [CrossRef]

157. Papagiannakopoulos, T.; Friedmann-Morvinski, D.; Neveu, P.; Dugas, J.C.; Gill, R.M.; Huillard, E.; Liu, C.; Zong, H.; Rowitch, D.H.; Barres, B.A.; et al. Pro-neural miR-128 is a glioma tumor suppressor that targets mitogenic kinases. Oncogene 2011, 31, 1884-1895. [CrossRef]

158. Zhang, Y.; Chao, T.; Li, R.; Liu, W.; Chen, Y.; Yan, X.; Gong, Y.; Yin, B.; Liu, W.; Qiang, B.; et al. MicroRNA-128 inhibits glioma cells proliferation by targeting transcription factor E2F3a. J. Mol. Med. 2009, 87, 43-51. [CrossRef]

159. Wuchty, S.; Arjona, D.; Li, A.; Kotliarov, Y.; Walling, J.; Ahn, S.; Zhang, A.; Marić, D.; Anolik, R.; Zenklusen, J.C.; et al. Prediction of Associations between microRNAs and Gene Expression in Glioma Biology. PLoS ONE 2011, 6, e14681. [CrossRef] 
160. Vo, D.T.; Qiao, M.; Smith, A.D.; Burns, S.C.; Brenner, A.J.; Penalva, L.O. The oncogenic RNA-binding protein Musashi1 is regulated by tumor suppressor miRNAs. RNA Biol. 2011, 8, 817-828. [CrossRef]

161. Drosos, Y.; Kouloukoussa, M.; Østvold, A.C.; Grundt, K.; Goutas, N.; Vlachodimitropoulos, D.; Havaki, S.; Kollia, P.; Kittas, C.; Marinos, E.; et al. NUCKS overexpression in breast cancer. Cancer Cell Int. 2009, 9, 19. [CrossRef]

162. Whitfeld, M.L.; Sherlock, G.; Saldanha, A.J.; Murray, J.I.; Ball, C.A.; Alexander, K.E.; Matese, J.C.; Perou, C.M.; Hurt, M.M.; Brown, P.O.; et al. Identifcation of genes periodically expressed in the human cell cycle and their expression in tumors. Mol. Biol. Cell 2002, 13, 1977-2000. [CrossRef] [PubMed]

163. Meijer, L.; Ostvold, A.C.; Walass, S.I.; Lund, T.; Laland, S.G. High-mobility-group proteins P1, I and Y as substrates of the M-phase-specific p34cdc2/cyclincdc13 kinase. Eur. J. Biochem. 1991, 196, 557-567. [CrossRef] [PubMed]

164. Walaas, S.I.; Ostvold, A.C.; Laland, S.G. Phosphorylation of P1, a high mobility group-like protein, catalyzed by casein kinase II, protein kinase C, cyclic AMP-dependent protein kinase and calcium/calmodulin-dependent protein kinase II. FEBS Lett. 1989, 258, 106-108. [CrossRef]

165. Ostvold, A.C.; Norum, J.H.; Mathiesen, S.; Wanvik, B.; Sefland, I.; Grundt, K. Molecular cloning of a mammalian nuclear phosphoprotein NUCKS, which serves as a substrate for Cdk1 in vivo. Eur. J. Biochem. 2001, 268, 2430-2440. [CrossRef] [PubMed]

166. Giunti, L.; Pantaleo, M.; Sardi, I.; Provenzano, A.; Magi, A.; Cardellicchio, S.; Castiglione, F.; Tattini, L.; Novara, F.; Buccoliero, A.M.; et al. Genome-wide copy number analysis in pediatric glioblastoma multiforme. Am. J. Cancer Res. 2014, 4, 293-303.

167. Lo, K.C.; Ma, C.; Bundy, B.N.; Pomeroy, S.L.; Eberhart, C.G.; Cowell, J.K. Gain of 1q is a potential univariate negative prognostic marker for survival in medulloblastoma. Clin. Cancer Res. 2007, 13, 7022-7028. [CrossRef]

168. Szponar, A.; Zubakov, D.; Pawlak, J.; Jauch, A.; Kovacs, G. Three genetic developmental stages of papillary renal cell tumors: Duplication of chromosome 1q marks fatal progression. Int. J. Cancer 2009, 124, 2071-2076. [CrossRef]

169. Balcárková, J.; Urbánková, H.; Scudla, V.; Holzerová, M.; Bacovský, J.; Indrák, K.; Jarosová, M. Gain of chromosome arm 1q in patients in relapse and progression of multiple myeloma. Cancer Genet. Cytogenet. 2009, 192, 68-72. [CrossRef]

170. Hirose, Y.; Aldape, K.; Bollen, A.; James, C.D.; Brat, D.; Lamborn, K.; Berger, M.; Feuerstein, B.G. Chromosomal abnormalities subdivide ependymal tumors into clinically relevant groups. Am. J. Pathol. 2001, 158, 1137-1143. [CrossRef]

171. Faria, C.; Miguéns, J.; Antunes, J.L.; Salgado, D.; Nunes, S.; Barroso, C.; Martins Mdo, C.; Nunes, V.M.; Roque, L. Pediatric brain tumors: Genetics and clinical outcome. J. Neurosurg. Pediatr. 2010, 5, 263-270. [CrossRef]

172. Giunti, L.; Da Ros, M.; De Gregorio, V.; Magi, A.; Landini, S.; Mazzinghi, B.; Buccoliero, A.M.; Genitori, L.; Giglio, S.; Sardi, I. A microRNA profile of pediatric glioblastoma: The role of NUCKS1 upregulation. Mol. Clin. Oncol. 2019, 10, 331-338. [CrossRef] [PubMed]

173. Sun, F.; Fu, H.; Liu, Q.; Tie, Y.; Zhu, J.; Xing, R.; Sun, Z.; Zheng, X. Downregulation of CCND1 and CDK6 by miR-34a induces cell cycle arrest. FEBS Lett. 2008, 582, 1564-1568. [CrossRef] [PubMed]

174. Liang, M.-L.; Hsieh, T.-H.; Ng, K.-H.; Tsai, Y.-N.; Tsai, C.-F.; Chao, M.-E.; Liu, D.-J.; Chu, S.-S.; Chen, W.; Liu, Y.-R.; et al. Downregulation of miR-137 and miR-6500-3p promotes cell proliferation in pediatric high-grade gliomas. Oncotarget 2016, 7, 19723-19737. [CrossRef] [PubMed]

175. Gong, W.; Zheng, J.; Liu, X.; Ma, J.; Liu, Y.; Xue, Y. Knockdown of NEAT1 restrained the malignant progression of glioma stem cells by activating microRNA let-7e. Oncotarget 2016, 7, 62208-62223. [CrossRef]

176. Novakova, J.; Slaby, O.; Vyzula, R.; Michalek, J. MicroRNA involvement in glioblastoma pathogenesis. Biochem. Biophys. Res. Commun. 2009, 386, 1-5. [CrossRef]

177. Göke, R.; Barth, P.; Schmidt, A.; Samans, B.; Lankat-Buttgereit, B. Programmed cell death protein 4 suppresses CDK1/cdc2 via induction of p21(Waf1/Cip1). Am. J. Physiol. Cell Physiol. 2004, 287, C1541-C1546. [CrossRef]

178. Yang, C.H.; Yue, J.; Pfeffer, S.R.; Fan, M.; Paulus, E.; Hosni-Ahmed, A.; Sims, M.; Qayyum, S.; Davidoff, A.M.; Handorf, C.R.; et al. MicroRNA-21 Promotes Glioblastoma Tumorigenesis by Down-regulating Insulin-like Growth Factor-binding Protein-3 (IGFBP3)*. J. Boil. Chem. 2014, 289, 25079-25087. [CrossRef]

179. Wang, P.; Liu, Y.H.; Yao, Y.L.; Li, Z.; Li, Z.Q.; Ma, J.; Xue, Y.X. Long non-coding RNA CASC2 suppresses malignancy in human gliomas by miR-21. Cell. Signal. 2015, 27, 275-282. [CrossRef] 
180. Le Sage, C.; Nagel, R.; A Egan, D.; Schrier, M.; Mesman, E.; Mangiola, A.; Anile, C.; Maira, G.; Mercatelli, N.; Ciafre', S.A.; et al. Regulation of the p27Kip1 tumor suppressor by miR-221 and miR-222 promotes cancer cell proliferation. EMBO J. 2007, 26, 3699-3708. [CrossRef]

181. Mao, J.; Zhang, M.; Zhong, M.; Zhang, Y.; Lv, K. MicroRNA-204, a direct negative regulator of ezrin gene expression, inhibits glioma cell migration and invasion. Mol. Cell Biochem. 2014, 396, 117-128. [CrossRef]

182. Song, S.; Fajol, A.; Tu, X.; Ren, B.; Shi, S. miR-204 suppresses the development and progression of human glioblastoma by targeting ATF2. Oncotarget 2016, 7, 70058-70065. [CrossRef] [PubMed]

183. Jiang, J.; Yang, J.; Wang, Z.; Wu, G.; Liu, F. TFAM is directly regulated by miR-23b in glioma. Oncol. Rep. 2013, 30, 2105-2110. [CrossRef] [PubMed]

184. Lee, H.-K.; Finniss, S.; Cazacu, S.; Bucris, E.; Ziv-Av, A.; Xiang, C.; Bobbitt, K.; Rempel, S.A.; Hasselbach, L.; Mikkelsen, T.; et al. Mesenchymal stem cells deliver synthetic microRNA mimics to glioma cells and glioma stem cells and inhibit their cell migration and self-renewal. Oncotarget 2013, 4, 346-361. [CrossRef]

185. Lee, H.K.; Bier, A.; Cazacu, S.; Finniss, S.; Xiang, C.; Twito, H.; Poisson, L.M.; Mikkelsen, T.; Slavin, S.; Jacoby, E.; et al. MicroRNA-145 Is Downregulated in Glial Tumors and Regulates Glioma Cell Migration by Targeting Connective Tissue Growth Factor. PLoS ONE 2013, 8, e54652. [CrossRef] [PubMed]

186. Speranza, M.C.; Frattini, V.; Pisati, F.; Kapetis, D.; Porrati, P.; Eoli, M.; Pellegatta, S.; Finocchiaro, G. NEDD9, a novel target of miR-145, increases the invasiveness of glioblastoma. Oncotarget 2012, 3, 723-734. [CrossRef]

187. Ruan, J.; Lou, S.; Dai, Q.; Mao, D.; Ji, J.; Sun, X. Tumor suppressor miR-181c attenuates proliferation, invasion, and self-renewal abilities in glioblastoma. Neuroreport 2015, 26, 66-73. [CrossRef] [PubMed]

188. Xi, Z.; Wang, P.; Xue, Y.; Shang, C.; Liu, X.; Ma, J.; Li, Z.; Li, Z.; Bao, M.; Liu, Y. Overexpression of miR-29a reduces the oncogenic properties of glioblastoma stem cells by downregulating Quaking gene isoform 6. Oncotarget 2017, 8, 24949-24963. [CrossRef] [PubMed]

189. Sun, J.; Jia, Z.; Li, B.; Zhang, A.; Wang, G.; Pu, P.; Chen, Z.; Wang, Z.; Yang, W. MiR-19 regulates the proliferation and invasion of glioma by RUNX3 via $\beta$-catenin/Tcf-4 signaling. Oncotarget 2017, 8, 110785-110796. [CrossRef] [PubMed]

190. Ma, C.; Zheng, C.; Bai, E.; Yang, K. miR-101 inhibits glioma cell invasion via the downregulation of COX-2. Oncol. Lett. 2016, 12, 2538-2544. [CrossRef]

191. Liu, N.; Zhang, L.; Wang, Z.; Cheng, Y.; Zhang, P.; Wang, X.; Wen, W.; Yang, H.; Liu, H.; Jin, W.-L.; et al. MicroRNA-101 inhibits proliferation, migration and invasion of human glioblastoma by targeting SOX9. Oncotarget 2017, 8, 19244-19254. [CrossRef]

192. Jin, Y.; Wang, J.; Han, J.; Luo, D.; Sun, Z. MiR-122 inhibits epithelial-mesenchymal transition in hepatocellular carcinoma by targeting Snail1 and Snail2 and suppressing WNT/ $\beta$-cadherin signaling pathway. Exp. Cell Res. 2017, 360, 210-217. [CrossRef] [PubMed]

193. Zhang, F.; Wan, M.; Xu, Y.; Li, Z.; Leng, K.; Kang, P.; Cui, Y.; Jiang, X. Long noncoding RNA PCAT1 regulates extrahepatic cholangiocarcinoma progression via the $\mathrm{Wnt} / \beta$-catenin-signaling pathway. Biomed. Pharmacother. 2017, 94, 55-62. [CrossRef] [PubMed]

194. Wang, G.; Zhao, Y.; Zheng, Y. MiR-122/Wnt/beta-catenin regulatory circuitry sustains glioma progression. Tumor Biol. 2014, 35, 8565-8572. [CrossRef]

195. Sun, J.; Zheng, G.; Gu, Z.; Guo, Z. MiR-137 inhibits proliferation and angiogenesis of human glioblastoma cells by targeting EZH2. J. Neuro Oncol. 2015, 122, 481-489. [CrossRef] [PubMed]

196. Lan, F.; Yu, H.; Hu, M.; Xia, T.; Yue, X. miR-144-3p exerts anti-tumor effects in glioblastoma by targeting c-Met. J. Neurochem. 2015, 135, 274-286. [CrossRef] [PubMed]

197. Zhang, P.; Sun, H.; Yang, B.; Luo, W.; Liu, Z.; Wang, J.; Zuo, Y. miR-152 regulated glioma cell proliferation and apoptosis via Runx2 mediated by DNMT1. Biomed. Pharmacother. 2017, 92, 690-695. [CrossRef] [PubMed]

198. Yan, Z.; Che, S.; Wang, J.; Jiao, Y.; Wang, C.; Meng, Q. miR-155 contributes to the progression of glioma by enhancing Wnt/ $\beta$-catenin pathway. Tumor Biol. 2015, 36, 5323-5331. [CrossRef]

199. Zhou, Y.; Peng, Y.; Liu, M.; Jiang, Y. MicroRNA-181b Inhibits Cellular Proliferation and Invasion of Glioma Cells via Targeting Sal-Like Protein 4. Oncol. Res. 2017, 25, 947-957. [CrossRef]

200. Li, P.; Lu, X.; Wang, Y.; Sun, L.; Qian, C.; Yan, W.; Liu, N.; You, Y.; Fu, Z. MiR-181b suppresses proliferation of and reduces chemoresistance to temozolomide in U87 glioma stem cells. J. Biomed. Res. 2010, 24, 436-443. [CrossRef] 
201. Xue, J.; Zhou, A.; Wu, Y.; Morris, S.-A.; Lin, K.; Amin, S.; Verhaak, R.; Fuller, G.N.; Xie, K.; Heimberger, A.B.; et al. miR-182-5p Induced by STAT3 Activation Promotes Glioma Tumorigenesis. Cancer Res. 2016, 76, 4293-4304. [CrossRef]

202. Pal, D.; Mukhopadhyay, D.; Ramaiah, M.J.; Sarma, P.; Bhadra, U.; Bhadra, M.P. Regulation of Cell Proliferation and Migration by miR-203 via GAS41/miR-10b Axis in Human Glioblastoma Cells. PLoS ONE 2016, 11, e0159092. [CrossRef] [PubMed]

203. Zhou, J.; Xu, T.; Yan, Y.; Qin, R.; Wang, H.; Zhang, X.; Huang, Y.; Wang, Y.; Lu, Y.; Fu, D.; et al. MicroRNA-326 Functions as a Tumor Suppressor in Glioma by Targeting the Nin One Binding Protein (NOB1). PLoS ONE 2013, 8, e68469. [CrossRef] [PubMed]

204. Yang, Y.N.; Zhang, X.H.; Wang, Y.M.; Zhang, X.; Gu, Z. miR-204 reverses temozolomide resistance and inhibits cancer initiating cells phenotypes by degrading FAP- $\alpha$ in glioblastoma. Oncol. Lett. 2018, 15, 7563-7570. [CrossRef] [PubMed]

205. Hirano, F.; Kaneko, K.; Tamura, H.; Dong, H.; Wang, S.; Ichikawa, M.; Rietz, C.; Flies, D.B.; Lau, J.S.; Zhu, G.; et al. Blockade of B7-H1 and PD-1 by monoclonal antibodies potentiates cancer therapeutic immunity. Cancer Res. 2005, 65, 1089-1096. [PubMed]

206. Dong, H.; Strome, S.E.; Salomao, D.R.; Tamura, H.; Hirano, F.; Flies, D.B.; Roche, P.C.; Lu, J.; Zhu, G.; Tamada, K.; et al. Tumor-associated B7-H1 promotes T-cell apoptosis: A potential mechanism of immune evasion. Nat. Med. 2002, 8, 793-800. [CrossRef] [PubMed]

207. Mazurek, M.; Litak, J.; Kamieniak, P.; Osuchowska, I.; Maciejewski, R.; Roliński, J.; Grajkowska, W.; Grochowski, C. Micro RNA Molecules as Modulators of Treatment Resistance, Immune Checkpoints Controllers and Sensitive Biomarkers in Glioblastoma Multiforme. Int. J. Mol. Sci. 2020, 21, 1507. [CrossRef]

208. Wintterle, S.; Schreiner, B.; Mitsdoerffer, M.; Schneider, D.; Chen, L.; Meyermann, R.; Weller, M.; Wiendl, H. Expression of the B7-related molecule B7-H1 by glioma cells: A potential mechanism of immune pa-ralysis. Cancer Res. 2003, 63, 7462-7467.

209. Wang, Q.; Lin, W.; Tang, X.; Li, S.; Guo, L.; Lin, Y.; Kwok, H.F. The Roles of microRNAs in Regulating the Expression of PD-1/PD-L1 Immune Checkpoint. Int. J. Mol. Sci. 2017, 18, 2540. [CrossRef]

210. Wei, J.; Nduom, E.; Kong, L.-Y.; Hashimoto, Y.; Xu, S.; Gabrusiewicz, K.; Ling, X.; Huang, N.; Qiao, W.; Zhou, S.; et al. MiR-138 exerts anti-glioma efficacy by targeting immune checkpoints. Neuro-Oncology 2015, 18, 639-648. [CrossRef]

211. Zampini, M.; Bisio, V.; Leszl, A.; Putti, M.C.; Menna, G.; Rizzari, C.; Pession, A.; Locatelli, F.; Basso, G.; Tregnago, C.; et al. A three-miRNA-based expression signature at diagnosis can predict occurrence of relapse in children with $\mathrm{t}(8 ; 21)$ RUNX1-RUNX1T1 acute myeloid leukaemia. Br. J. Haematol. 2018, 183, 298-301. [CrossRef]

212. Nie, C.L.; Ren, W.H.; Ma, Y.; Xi, J.S.; Han, B. Circulating miR-125b as a biomarker of Ewing's sarcoma in Chinese children. Genet. Mol. Res. 2015, 14, 19049-19056. [CrossRef] [PubMed]

213. Lee, Y.Y.; Yang, Y.P.; Huang, M.C.; Wang, M.L.; Yen, S.H.; Huang, P.I.; Chen, Y.W.; Chiou, S.H.; Lan, Y.T.; Ma, H.I.; et al. MicroRNA142-3p promotes tumor-initiating and radioresistant properties in malignant pediatric brain tumors. Cell Transplant. 2014, 23, 669-690. [CrossRef] [PubMed]

214. Uziel, T.; Karginov, F.V.; Xie, S.; Parker, J.S.; Wang, Y.D.; Gajjar, A.; He, L.; Ellison, D.; Gilbertson, R.J.; Hannon, G.; et al. The miR-17-92 cluster collaborates with the Sonic Hedgehog pathway in medulloblastoma. Proc. Natl. Acad. Sci. USA 2009, 106, 2812-2817. [CrossRef] [PubMed]

215. Schulte, J.H.; Horn, S.; Otto, T.; Samans, B.; Heukamp, L.C.; Eilers, U.-C.; Krause, M.; Astrahantseff, K.; Klein-Hitpass, L.; Buettner, R.; et al. MYCN regulates oncogenic MicroRNAs in neuroblastoma. Int. J. Cancer 2008, 122, 699-704. [CrossRef] [PubMed]

216. Ferretti, E.; de Smaele, E.; Miele, E.; Laneve, P.; Po, A.; Pelloni, M.; Paganelli, A.; di Marcotullio, L.; Caffarelli, E.; Screpanti, I.; et al. Concerted microRNA control of Hedgehog signalling in cerebellar neuronal progenitor and tumour cells. EMBO J. 2008, 27, 2616-2627. [CrossRef] [PubMed]

217. Garzia, L.; Andolfo, I.; Cusanelli, E.; Marino, N.; Petrosino, G.; De Martino, D.; Esposito, V.; Galeone, A.; Navas, L.; Esposito, S.; et al. MicroRNA-199b-5p Impairs Cancer Stem Cells through Negative Regulation of HES1 in Medulloblastoma. PLoS ONE 2009, 4, e4998. [CrossRef]

218. Chen, Y.; Stallings, R.L. Differential patterns ofmicroRNA expression in neuroblastoma are correlated with prognosis, differentiation, and apoptosis. Cancer Res. 2007, 67, 976-983. [CrossRef] 
219. Ferretti, E.; De Smaele, E.; Po, A.; Di Marcotullio, L.; Tosi, E.; Espinola, M.S.B.; Di Rocco, C.; Riccardi, R.; Giangaspero, F.; Farcomeni, A.; et al. MicroRNA profiling in human medulloblastoma. Int. J. Cancer 2009, 124, 568-577. [CrossRef]

220. Pierson, J.; Hostager, B.; Fan, R.; Vibhakar, R. Regulation of cyclin dependent kinase 6 by microRNA 124 in medulloblastoma. J. Neurooncol. 2008, 90, 1-7. [CrossRef]

221. Darrigo Júnior, L.G.; Lira, R.C.P.; Fedatto, P.F.; Marco Antonio, D.S.; Valera, E.T.; Aguiar, S.; Yunes, J.A.; Brandalise, S.R.; Neder, L.; Saggioro, F.P.; et al. MicroRNA profile of pediatric pilocytic astrocytomas identifies two tumor-specific signatures when compared to non-neoplastic white matter. J. Neurooncol. 2019, 141, 373-382. [CrossRef]

222. Yuan, M.; Da Silva, A.C.A.L.; Arnold, A.; Okeke, L.; Ames, H.; Correa-Cerro, L.S.; Vizcaino, M.A.; Ho, C.-Y.; Eberhart, C.G.; Rodriguez, F.J. MicroRNA (miR) 125b regulates cell growth and invasion in pediatric low grade glioma. Sci. Rep. 2018, 8, 12506. [CrossRef] [PubMed]

223. Bookland, M.; Tang-Schomer, M.; Gillan, E.; Kolmakova, A. Circulating serum oncologic miRNA in pediatric juvenile pilocytic astrocytoma patients predicts mural nodule volume. Acta Neurochir. 2018, 160, 1-11. [CrossRef] [PubMed]

224. Pan, L.; Meng, L.; Liang, F.; Cao, L. miR-188 suppresses tumor progression by targeting SOX4 in pediatric osteosarcoma. Mol. Med. Rep. 2018, 18,441-446. [CrossRef] [PubMed]

225. Shu, C.; Wang, Q.; Yan, X.; Wang, J. Prognostic and microRNA profile analysis for CD44 positive expression pediatric posterior fossa ependymoma. Clin. Transl. Oncol. 2018, 20, 1439-1447. [CrossRef] [PubMed]

226. Catanzaro, G.; Besharat, Z.M.; Miele, E.; Chiacchiarini, M.; Po, A.; Carai, A.; Marras, C.E.; Antonelli, M.; Badiali, M.; Raso, A.; et al. The miR-139-5p regulates proliferation of supratentorial paediatric low-grade gliomas by targeting the PI3K/AKT/mTORC1 signalling. Neuropathol. Appl. Neurobiol. 2018, 44, 687-706. [CrossRef] [PubMed]

227. López-Aguilar, J.E.; Velázquez-Flores, M.A.; Simón-Martínez, L.A.; Ávila-Miranda, R.; Rodríguez-Florido, M.A.; Ruiz-Esparza Garrido, R. Circulating microRNAs as Biomarkers for Pediatric Astrocytomas. Arch. Med. Res. 2017, 48, 323-332. [CrossRef]

228. Ruiz Esparza-Garrido, R.; Rodríguez-Corona, J.M.; López-Aguilar, J.E.; Rodríguez-Florido, M.A.; Velázquez-Wong, A.C.; Viedma-Rodríguez, R.; Salamanca-Gómez, F.; Velázquez-Flores, M.Á. Differentially Expressed Long Non-Coding RNAs Were Predicted to Be Involved in the Control of Signaling Pathways in Pediatric Astrocytoma. Mol. Neurobiol. 2017, 54, 6598-6608. [CrossRef]

229. Braoudaki, M.; Lambrou, G.I.; Giannikou, K.; Papadodima, S.A.; Lykoudi, A.; Stefanaki, K.; Sfakianos, G.; Kolialexi, A.; Tzortzatou-Stathopoulou, F.; Tzetis, M.; et al. miR-15a and miR-24-1 as putative prognostic microRNA signatures for pediatric pilocytic astrocytomas and ependymomas. Tumor Biol. 2016, 37,9887-9897. [CrossRef]

230. Feng, F.; Kuai, D.; Wang, H.; Li, T.; Miao, W.; Liu, Y.; Fan, Y. Reduced expression of microRNA-497 is associated with greater angiogenesis and poor prognosis in human gliomas. Hum. Pathol. 2016, 58, 47-53. [CrossRef]

231. Wu, Z.; Wang, L.; Li, G.; Liu, H.; Fan, F.; Li, Z.; Li, Y.; Gao, G. Increased expression of microRNA-9 predicts an unfavorable prognosis in human glioma. Mol. Cell. Biochem. 2013, 384, 263-268. [CrossRef]

232. Liu, F.; Xiong, Y.; Zhao, Y.; Tao, L.; Zhang, Z.; Zhang, H.; Liu, Y.; Feng, G.; Li, B.; He, L.; et al. Identification of aberrant microRNA expression pattern in pediatric gliomas by microarray. Diagn. Pathol. 2013, 8, 158. [CrossRef]

233. He, J.; Deng, Y.; Yang, G.; Xie, W. MicroRNA-203 down-regulation is associated with unfavorable prognosis in human glioma. J. Surg. Oncol. 2013, 108, 121-125. [CrossRef]

234. Minturn, J.E.; Fisher, M.J. Gliomas in children. Curr. Treat Options Neurol. 2013, 15, 316-327. [CrossRef] [PubMed]

235. Hargrave, D. Paediatric high and low grade glioma: The impact of tumour biology on current and future therapy. Br. J. Neurosurg. 2009, 23, 351-363. [CrossRef] [PubMed]

236. Fangusaro, J. Pediatric high grade glioma: A review and update on tumor clinical characteristics and biology. Front. Oncol. 2012, 2, 105. [CrossRef] [PubMed] 
237. Pollack, I.F.; Hamilton, R.L.; James, C.D.; Finkelstein, S.D.; Burnham, J.; Yates, A.J.; Holmes, E.J.; Zhou, T.; Finlay, J.L. Children's Oncology Group. Rarity of PTEN deletions and EGFR amplification in malignant gliomas of childhood: Results from the Children's Cancer Group 945 cohort. J. Neurosurg. 2006, 105 (Suppl. 5), 418-424. [PubMed]

238. Birks, D.K.; Barton, V.N.; Donson, A.M.; Handler, M.H.; Vibhakar, R.; Foreman, N.K. Survey of MicroRNA expression in pediatric brain tumors. Pediatr. Blood Cancer 2011, 56, 211-216. [CrossRef]

239. Miele, E.; Buttarelli, F.R.; Arcella, A.; Begalli, F.; Garg, N.; Silvano, M.; Po, A.; Baldi, C.; Carissimo, G.; Antonelli, M.; et al. High-throughput microRNA profiling of pediatric high-grade gliomas. Neuro-Oncology 2013, 16, 228-240. [CrossRef]

240. Jha, P.; Agrawal, R.; Pathak, P.; Kumar, A.; Purkait, S.; Mallik, S.; Suri, V.; Chand Sharma, M.; Gupta, D.; Suri, A.; et al. Genome-wide small noncoding RNA profiling of pediatric high-grade gliomas reveals deregulation of several miRNAs, identifies downregulation of snoRNA cluster HBII-52 and delineates H3F3A and TP53 mutant-specific miRNAs and snoRNAs. Int. J. Cancer 2015, 137, 2343-2353. [CrossRef]

241. Paugh, B.S.; Qu, C.; Jones, C.; Liu, Z.; Adamowicz-Brice, M.; Zhang, J.; Bax, D.A.; Coyle, B.; Barrow, J.; Hargrave, D.; et al. Integrated molecular genetic profiling of pediatric high-grade gliomas reveals key differences with the adult disease. J. Clin. Oncol. 2010, 28, 3061-3068. [CrossRef]

242. Louis, D.N.; Ohgaki, H.; Wiestler, O.D.; Cavenee, W.K.; Burger, P.C.; Jouvet, A.; Scheithauer, B.W.; Kleihues, P. The 2007 WHO classification of tumours of the central nervous system. Acta Neuropathol. 2007, 114, 97-109. [CrossRef] [PubMed]

243. Pollack, I.F.; Boyett, J.M.; Yates, A.J.; Burger, P.C.; Gilles, F.H.; Davis, R.L.; Finlay, J.L. Children's Cancer Group: The influence of central review on outcome associations in childhood malignant gliomas: Results from the CCG-945 experience. Neuro Oncol. 2003, 5, 197-207. [CrossRef] [PubMed]

244. Nakamura, M.; Shimada, K.; Ishida, E.; Higuchi, T.; Nakase, H.; Sakaki, T.; Konishi, N. Molecular pathogenesis of pediatric astrocytic tumors. Neuro Oncol. 2007, 9, 113-123. [CrossRef] [PubMed]

245. Ohgaki, H.; Kleihues, P. Genetic pathways to primary and secondary glioblastoma. Am. J. Pathol. 2007, 170, 1445-1453. [CrossRef]

246. Pollack, I.F.; Finkelstein, S.D.; Woods, J.; Burnham, J.; Holmes, E.J.; Hamilton, R.L.; Yates, A.J.; Boyett, J.M.; Finlay, J.L.; Sposto, R. Children's Cancer Group: Expression of p53 and prognosis in children with malignant gliomas. N. Engl. J. Med. 2002, 346, 420-427. [CrossRef]

247. Ganigi, P.M.; Santosh, V.; Anandh, B.; Chandramouli, B.A.; Sastry Kolluri, V.R. Expression of p53, EGFR, $\mathrm{pRb}$ and bcl-2 proteins in pediatric glioblastoma multiforme: A study of 54 patients. Pediatr. Neurosurg. 2005, 41, 292-299. [CrossRef] [PubMed]

248. Gómez Del Pulgar, T.; De Ceballos, M.L.; Guzmán, M.; Velasco, G. Cannabinoids protect astrocytes from ceramide-induced apoptosis through the phosphatidylinositol 3-kinase/protein kinase B pathway. J. Biol. Chem. 2002, 277, 36527-36533. [CrossRef]

249. King, D.; Yeomanson, D.; Bryant, H.E. PI3King the lock: Targeting the PI3K/Akt/mTOR pathway as a novel therapeutic strategy in neuroblastoma. J. Pediatr. Hematol. Oncol. 2015, 37, 245-251. [CrossRef]

250. Ojeda, L.; Gao, J.; Hooten, K.G.; Wang, E.; Thonhoff, J.R.; Dunn, T.J.; Gao, T.; Wu, P. Critical Role of PI3K/Akt/GSK3 $\beta$ in Motoneuron Specification from Human Neural Stem Cells in Response to FGF2 and EGF. PLoS ONE 2011, 6, e23414. [CrossRef]

251. Rizzo, D.; Ruggiero, A.; Martini, M.; Rizzo, V.; Maurizi, P.; Riccardi, R. Molecular Biology in Pediatric High-Grade Glioma: Impact on Prognosis and Treatment. Biomed Res. Int. 2015, 2015, 215135. [CrossRef]

252. Rafalski, V.A.; Brunet, A. Energy metabolism in adult neural stem cell fate. Prog. Neurobiol. 2011, 93, $182-203$. [CrossRef] [PubMed]

253. Chu, E.C.; Tarnawski, A.S. PTEN regulatory functions in tumor suppression and cell biology. Med. Sci. Monit. 2004, 10, RA235-RA241. [PubMed]

254. Hopkins, B.D.; Hodakoski, C.; Barrows, D.; Mense, S.M.; Parsons, R.E. PTEN function: The long and the short of it. Trends Biochem. Sci. 2014, 39, 183-190. [CrossRef] [PubMed]

255. Smith, J.S.; Tachibana, I.; Passe, S.M.; Huntley, B.K.; Borell, T.J.; Iturria, N.; O’Fallon, J.R.; Schaefer, P.L.; Scheithauer, B.W.; James, C.D.; et al. PTEN mutation, EGFR amplification, and outcome in patients with anaplastic astrocytoma and glioblastoma multiforme. J. Natl. Cancer Inst. 2001, 93, 1246-1256. [CrossRef] [PubMed] 
256. Kraus, J.A.; Felsberg, J.; Tonn, J.C.; Reifenberger, G.; Pietsch, T. Molecular genetic analysis of the TP53, PTEN, CDKN2A, EGFR, CDK4 and MDM2 tumour-associated genes in supratentorial primitive neuroectodermal tumours and glioblastomas of childhood. Neuropathol. Appl. Neurobiol. 2002, 28, 325-333. [CrossRef] [PubMed]

257. Raffel, C.; Frederick, L.; O'Fallon, J.R.; Atherton-Skaff, P.; Perry, A.; Jenkins, R.B.; James, C.D. Analysis of oncogene and tumor suppressor gene alterations in pediatric malignant astrocytomas reveals reduced survival for patients with PTEN mutations. Clin. Cancer Res. 1999, 5, 4085-4090. [PubMed]

258. Bax, D.A.; Mackay, A.; E Little, S.; Carvalho, D.; Viana-Pereira, M.; Tamber, N.; Grigoriadis, A.; Ashworth, A.; Reis, R.M.; Ellison, D.W.; et al. A Distinct Spectrum of Copy Number Aberrations in Pediatric High-Grade Gliomas. Clin. Cancer Res. 2010, 16, 3368-3377. [CrossRef]

259. Jones, C.; Perryman, L.; Hargrave, D. Paediatric and adult malignant glioma: Close relatives or distant cousins? Nat. Rev. Clin. Oncol. 2012, 9, 400-413. [CrossRef]

260. Zhang, C.-Z.; Han, L.; Zhang, A.-L.; Fu, Y.C.; Xiao, Y.; Wang, G.-X.; Jia, Z.-F.; Pu, P.-Y.; Zhang, Q.-Y.; Kang, C.-S. MicroRNA-221 and microRNA-222 regulate gastric carcinoma cell proliferation and radioresistance by targeting PTEN. BMC Cancer 2010, 10, 367.

261. Meng, F.; Henson, R.; Wehbe-Janek, H.; Ghoshal, K.; Jacob, S.T.; Patel, T. MicroRNA-21 regulates expression of the PTEN tumor suppressor gene in human hepatocellular cancer. Gastroenterology 2007, 133, 647-658. [CrossRef]

262. Kim, H.; Huang, W.; Jiang, X.; Pennicooke, B.; Park, P.J.; Johnson, M.D. Integrative genome analysis reveals an oncomir/oncogene cluster regulating glioblastoma survivorship. Proc. Natl. Acad. Sci. USA 2010, 107, 2183-2188. [CrossRef]

263. Olive, V.; Jiang, I.; He, L. mir-17-92, a cluster of miRNAs in the midst of the cancer network. Int. J. Biochem. Cell Biol. 2010, 42, 1348-1354. [CrossRef] [PubMed]

264. Murphree, A.L.; Benedict, W. Retinoblastoma: Clues to human oncogenesis. Science 1984, 223, $1028-1033$. [CrossRef] [PubMed]

265. Ingham, P.W.; Nakano, Y.; Seger, C. Mechanisms and functions of Hedgehog signalling across the metazoa. Nat. Rev. Genet. 2011, 12, 393-406. [CrossRef]

266. Clement, V.; Sanchez, P.; de Tribolet, N.; Radovanovic, I.; Ruiz i Altaba, A. HEDGEHOG-GLI1 signaling regulates human glioma growth, cancer stem cell self-renewal, and tumorigenicity. Curr. Biol. 2007, 17, 165-172. [CrossRef] [PubMed]

267. Dahmane, N.; Sánchez, P.; Gitton, Y.; Palma, V.; Sun, T.; Beyna, M.; Weiner, H.; I Altaba, A.R. The Sonic Hedgehog-Gli pathway regulates dorsal brain growth and tumorigenesis. Development 2001, 128, 5201-5212.

268. Northcott, P.A.; Fernandez, L.A.; Hagan, J.P.; Ellison, D.W.; Grajkowska, W.; Gillespie, Y.; Grundy, R.; Van Meter, T.; Rutka, J.T.; Croce, V.; et al. The miR-17/92 polycistron is up-regulated in sonic hedgehog-driven medulloblastomas and induced by N-myc in sonic hedgehog-treated cerebellar neural precursors. Cancer Res. 2009, 69, 3249-3255. [CrossRef]

269. Williams, L.T. Signal transduction by the platelet-derived growth factor receptor. Science 1989, 243, 1564-1570. [CrossRef]

270. Sung, T.; Miller, D.C.; Hayes, R.L.; Alonso, M.; Yee, H.; Newcomb, E.W. Preferential inactivation of the p53 tumor suppressor pathway and lack of EGFR amplification distinguish de novo high grade pediatric astrocytomas from de novo adult astrocytomas. Brain Pathol. 2000, 10, 249-259. [CrossRef]

271. Puget, S.; Philippe, C.; Bax, D.A.; Job, B.; Varlet, P.; Junier, M.-P.; Andreiuolo, F.; Carvalho, D.; Reis, R.; Guerrini-Rousseau, L.; et al. Mesenchymal Transition and PDGFRA Amplification/Mutation Are Key Distinct Oncogenic Events in Pediatric Diffuse Intrinsic Pontine Gliomas. PLoS ONE 2012, 7, e30313. [CrossRef]

272. Sturm, D.; Witt, H.; Hovestadt, V.; Quang, D.A.K.; Jones, D.T.W.; Konermann, C.; Pfaff, E.; Tönjes, M.; Sill, M.; Bender, S.; et al. Hotspot Mutations in H3F3A and IDH1 Define Distinct Epigenetic and Biological Subgroups of Glioblastoma. Cancer Cell 2012, 22, 425-437. [CrossRef] [PubMed]

273. Libermann, T.A.; Nusbaum, H.R.; Razon, N.; Kris, R.; Lax, I.; Soreq, H.; Whittle, N.; Waterfield, M.D.; Ullrich, A.; Schlessinger, J. Amplification, enhanced expression and possible rearrangement of EGF receptor gene in primary human brain tumours of glial origin. Nature 1985, 313, 144-147. [CrossRef] [PubMed]

274. Erlandsson, A.; Enarsson, M.; Forsberg-Nilsson, K. Immature neurons from CNS stem cells proliferate in response to platelet-derived growth factor. J. Neurosci. 2001, 21, 3483-3491. [CrossRef] [PubMed] 
275. Wang, D.; Huang, H.J.; Kazlauskas, A.; Cavenee, W.K. Induction of vascular endothelial growth factor expression in endothelial cells by platelet-derived growth factor through the activation of phosphatidylinositol 3-kinase. Cancer Res. 1999, 59, 1464-1472.

276. Holland, E.C.; Hively, W.P.; DePinho, R.A.; Varmus, H.E. A constitutively active epidermal growth factor receptor cooperates with disruption of G1 cell-cycle arrest pathways to induce glioma-like lesions in mice. Genes Dev. 1998, 12, 3675-3685. [CrossRef]

277. Ding, H.; Shannon, P.; Lau, N.; Wu, X.; Roncari, L.; Baldwin, R.L.; Takebayashi, H.; Nagy, A.; Gutmann, D.H.; Guha, A. Oligodendrogliomas result from the expression of an activated mutant epidermal growth factor receptor in a RAS transgenic mouse astrocytoma model. Cancer Res. 2003, 63, 1106-1113.

278. Tchougounova, E.; Kastemar, M.; Bråsäter, D.; Holland, E.C.; Westermark, B.; Uhrbom, L. Loss of Arf causes tumor progression of PDGFB-induced oligodendroglioma. Oncogene 2007, 26, 6289-6296. [CrossRef]

279. Lindberg, N.; Kastemar, M.; Olofsson, T.; Smits, A.; Uhrbom, L. Oligodendrocyte progenitor cells can act as cell of origin for experimental glioma. Oncogene 2009, 28, 2266-2275. [CrossRef]

280. Yang, Y.; Dodbele, S.; Park, T.; Glass, R.; Bhat, K.; Sulman, E.P.; Zhang, Y.; Abounader, R. MicroRNA-29a inhibits glioblastoma stem cells and tumor growth by regulating the PDGF pathway. J. Neurooncol. 2019, 145, 23-34. [CrossRef]

281. Costa, P.M.; Cardoso, A.L.; Pereira de Almeida, L.F.; Bruce, J.N.; Canoll, P.; Pedroso de Lima, M.C. PDGF-B-mediated downregulation of miR-21: New insights into PDGF signaling in glioblastoma. Hum. Mol. Genet. 2012, 21, 5118-5130. [CrossRef]

282. Dang, L.; White, D.W.; Gross, S.; Bennett, B.D.; Bittinger, M.A.; Driggers, E.M.; Fantin, V.R.; Jang, H.G.; Jin, S.; Keenan, M.C.; et al. Cancer-associated IDH1 mutations produce 2-hydroxyglutarate. Nature 2009, 462, 739-744. [CrossRef] [PubMed]

283. Eckel-Passow, J.E.; Lachance, D.H.; Molinaro, A.M.; Walsh, K.M.; Decker, P.A.; Sicotte, H.; Pekmezci, M.; Rice, T.; Kosel, M.L.; Smirnov, I.V.; et al. Glioma Groups Based on 1p/19q, IDH, and TERT Promoter Mutations in Tumors. N. Engl. J. Med. 2015, 372, 2499-2508. [CrossRef] [PubMed]

284. Halatsch, M.E.; Löw, S.; Hielscher, T.; Schmidt, U.; Unterberg, A.; Vougioukas, V.I. Epidermal growth factor receptor pathway gene expressions and biological response of glioblastoma multiforme cell lines to erlotinib. Anticancer Res. 2008, 28, 3725-3728. [PubMed]

285. Antonelli, M.; Buttarelli, F.R.; Arcella, A.; Nobusawa, S.; Donofrio, V.; Oghaki, H.; Giangaspero, F. Prognostic significance of histological grading, p53 status, YKL-40 expression, and IDH1 mutations in pediatric high-grade gliomas. J. Neurooncol. 2010, 99, 209-215. [CrossRef] [PubMed]

286. Yan, H.; Parsons, D.W.; Jin, G.; McLendon, R.; Rasheed, B.A.; Yuan, W.; Kos, I.; Batinic-Haberle, I.; Jones, S.; Riggins, G.J.; et al. IDH1 and IDH2 mutations in gliomas. N. Engl. J. Med. 2009, 360, 765-773. [CrossRef]

287. Setty, P.; Hammes, J.; Rothämel, T.; Vladimirova, V.; Kramm, C.M.; Pietsch, T.; Waha, A. A Pyrosequencing-Based Assay for the Rapid Detection of IDH1 Mutations in Clinical Samples. J. Mol. Diagn. 2010, 12, 750-756. [CrossRef]

288. Schiffman, J.D.; Hodgson, J.G.; Vandenberg, S.R.; Flaherty, P.; Polley, M.-Y.C.; Yu, M.; Fisher, P.; Rowitch, D.H.; Ford, J.M.; Berger, M.S.; et al. Oncogenic BRAF mutation with CDKN2A inactivation is characteristic of a subset of pediatric malignant astrocytomas. Cancer Res. 2010, 70, 512-519. [CrossRef]

289. De Carli, E.; Wang, X.; Puget, S. IDH1 and IDH2 mutations in gliomas. N. Engl. J. Med. 2009, 360, $2248-2249$. [CrossRef]

290. Balss, J.; Meyer, J.; Mueller, W.; Korshunov, A.; Hartmann, C.; von Deimling, A. Analysis of the IDH1 codon 132 mutation in brain tumors. Acta Neuropathol. 2008, 116, 597-602. [CrossRef]

291. Haque, T.; Faury, D.; Albrecht, S.; Lopez-Aguilar, E.; Hauser, P.; Garami, M.; Hanzely, Z.; Bognár, L.; Del Maestro, R.F.; Atkinson, J.; et al. Gene Expression Profiling from Formalin-Fixed Paraffin-Embedded Tumors of Pediatric Glioblastoma. Clin. Cancer Res. 2007, 13, 6284-6292. [CrossRef]

292. Johnson, R.; Wright, K.D.; Gilbertson, R.J. Molecular profiling of pediatric brain tumors: Insight into biology and treatment. Curr. Oncol. Rep. 2009, 11, 68-72. [CrossRef] [PubMed]

293. Jha, P.; Patric, I.R.P.; Shukla, S.; Pathak, P.; Pal, J.; Sharma, V.; Thinagararanjan, S.; Santosh, V.; Suri, V.; Sharma, M.C.; et al. Genome-wide methylation profiling identifies an essential role of reactive oxygen species in pediatric glioblastoma multiforme and validates a methylome specific for $\mathrm{H} 3$ histone family $3 \mathrm{~A}$ with absence of G-CIMP/isocitrate dehydrogenase 1 mutation. Neuro-Oncology 2014, 16, 1607-1617. [CrossRef] [PubMed] 
294. Parsons, D.W.; Jones, S.; Zhang, X.; Lin, J.C.-H.; Leary, R.J.; Angenendt, P.; Mankoo, P.; Carter, H.; Siu, I.-M.; Gallia, G.L.; et al. An Integrated Genomic Analysis of Human Glioblastoma Multiforme. Science 2008, 321, 1807-1812. [CrossRef] [PubMed]

295. Ichimura, K.; Pearson, D.M.; Kocialkowski, S.; Bäcklund, L.M.; Chan, R.; Jones, D.T.; Collins, V.P. IDH1 mutations are present in the majority of common adult gliomas but rare in primary glioblastomas. Neuro Oncol. 2009, 11, 341-347. [CrossRef] [PubMed]

296. Hartmann, C.; Meyer, J.; Balss, J.; Capper, D.; Mueller, W.; Christians, A.; Felsberg, J.; Wolter, M.; Mawrin, C.; Wick, W.; et al. Type and frequency of IDH1 and IDH2 mutations are related to astrocytic and oligodendroglial differentiation and age: A study of 1,010 diffuse gliomas. Acta Neuropathol. 2009, 118, 469-474. [CrossRef]

297. Pollack, I.F.; Hamilton, R.L.; Sobol, R.W.; Nikiforova, M.N.; Lyons-Weiler, M.A.; LaFramboise, W.A.; Burger, P.C.; Brat, D.J.; Rosenblum, M.K.; Holmes, E.J.; et al. IDH1 mutations are common in malignant gliomas arising in adolescents: A report from the Children's Oncology Group. Child's Nerv. Syst. 2010, 27, 87-94. [CrossRef]

298. Wang, Z.; Bao, Z.; Yan, W.; You, G.; Wang, Y.; Li, X.; Zhang, W. Isocitrate dehydrogenase 1 (IDH1) mutation-specific microRNA signature predicts favorable prognosis in glioblastoma patients with IDH1 wild type. J. Exp. Clin. Cancer Res. 2013, 32, 59. [CrossRef]

299. Simon, J.A.; Kingston, R.E. Mechanisms of polycomb gene silencing: Knowns and unknowns. Nat. Rev. Mol. Cell Biol. 2009, 10, 697-708. [CrossRef]

300. Gielen, G.H.; Gessi, M.; Hammes, J.; Kramm, C.M.; Waha, A.; Pietsch, T. H3F3A K27M mutation in pediatric CNS tumors: A marker for diffuse high-grade astrocytomas. Am. J. Clin. Pathol. 2013, 139, 345-349. [CrossRef]

301. Khuong-Quang, N.-A.; Buczkowicz, P.; Rakopoulos, P.; Liu, X.-Y.; Fontebasso, A.M.; Bouffet, E.; Bartels, U.; Albrecht, S.; Schwartzentruber, J.; Letourneau, L.; et al. K27M mutation in histone H3.3 defines clinically and biologically distinct subgroups of pediatric diffuse intrinsic pontine gliomas. Acta Neuropathol. 2012, 124, 439-447. [CrossRef]

302. Wu, G.; Broniscer, A.; McEachron, T.A.; Lu, C.; Paugh, B.S.; Becksfort, J.; Qu, C.; Ding, L.; Huether, R.; Parker, M.; et al. Somatic histone $\mathrm{H} 3$ alterations in pediatric diffuse intrinsic pontine gliomas and non-brainstem glioblastomas. Nat. Genet. 2012, 44, 251-253. [CrossRef] [PubMed]

303. Schwartzentruber, J.; Korshunov, A.; Liu, X.-Y.; Jones, D.T.W.; Pfaff, E.; Jacob, K.; Sturm, D.; Fontebasso, A.M.; Quang, D.A.K.; Tönjes, M.; et al. Driver mutations in histone H3.3 and chromatin remodelling genes in paediatric glioblastoma. Nature 2012, 482, 226-231. [CrossRef] [PubMed]

304. Jha, P.; Suri, V.; Singh, G.; Jha, P.; Purkait, S.; Pathak, P.; Sharma, V.; Sharma, M.C.; Suri, A.; Gupta, D.; et al. Characterization of Molecular Genetic Alterations in GBMs Highlights a Distinctive Molecular Profile in Young Adults. Diagn. Mol. Pathol. 2011, 20, 225-232. [CrossRef] [PubMed]

305. Ganci, F.; Sacconi, A.; Ben-Moshe, N.B.; Manciocco, V.; Sperduti, I.; Strigari, L.; Covello, R.; Benevolo, M.; Pescarmona, E.; Domany, E.; et al. Expression of TP53 mutation-associated microRNAs predicts clinical outcome in head and neck squamous cell carcinoma patients. Ann. Oncol. 2013, 24, 3082-3088. [CrossRef] [PubMed]

306. Chu, S.H.; Ma, Y.B.; Feng, D.F.; Li, Z.Q.; Jiang, P.C. Correlation between satb1 and Bcl-2 expression in human glioblastoma multiforme. Mol. Med. Rep. 2013, 7, 139-143. [CrossRef]

307. Verginelli, F.; Perin, A.; Dali, R.; Fung, K.H.; Lo, R.; Longatti, P.; Guiot, M.-C.; Del Maestro, R.F.; Rossi, S.; Di Porzio, U.; et al. Transcription factors FOXG1 and Groucho/TLE promote glioblastoma growth. Nat. Commun. 2013, 4, 2956. [CrossRef]

308. D’Urso, P.I.; D’Urso, O.F.; Storelli, C.; Mallardo, M.; Gianfreda, C.D.; Montinaro, A.; Cimmino, A.; Pietro, C.; Marsigliante, S. miR-155 is up-regulated in primary and secondary glioblastoma and promotes tumour growth by inhibiting GABA receptors. Int. J. Oncol. 2012, 41, 228-234.

309. Wang, Q.; Wang, L.; Li, D.; Deng, J.; Zhao, Z.; He, S.; Zhang, Y.; Tu, Y. Kinesin family member 14 is a candidate prognostic marker for outcome of glioma patients. Cancer Epidemiol. 2013, 37, 79-84. [CrossRef]

310. Corson, T.W.; Gallie, B.L. KIF14 mRNA expression is a predictor of grade and outcome in breast cancer. Int. J. Cancer 2006, 119, 1088-1094. [CrossRef]

311. Thériault, B.L.; Pajovic, S.; Bernardini, M.Q.; Shaw, P.A.; Gallie, B.L. Kinesin family member 14: An independent prognostic marker and potential therapeutic target for ovarian cancer. Int. J. Cancer 2012, 130, 1844-1854. [CrossRef] 
312. Corson, T.W.; Zhu, C.Q.; Lau, S.K.; Shepherd, F.A.; Tsao, M.S.; Gallie, B.L. KIF14 messenger RNA expression is independently prognostic for outcome in lung cancer. Clin. Cancer Res. 2007, 13, 3229-3234. [CrossRef] [PubMed]

313. Chung, V.; Heath, E.I.; Schelman, W.R.; Johnson, B.M.; Kirby, L.C.; Lynch, K.M.; Botbyl, J.D.; Lampkin, T.A.; Holen, K.D. First-time-in-human study of GSK923295, a novel antimitotic inhibitor of centromere-associated protein E (CENP-E), in patients with refractory cancer. Cancer Chemother. Pharmacol. 2012, 69, 733-741. [CrossRef] [PubMed]

314. Liu, Z.-J.; Ling, K.; Wu, X.; Cao, J.; Liu, B.; Li, S.; Shi, Q.; Cai, Y.; Yan, C.; Zhang, Y.; et al. Reduced expression of cenp-e in human hepatocellular carcinoma. J. Exp. Clin. Cancer Res. 2009, 28, 156. [CrossRef] [PubMed]

315. Agarwal, R.; Gonzalez-Angulo, A.-M.; Myhre, S.; Carey, M.; Lee, J.-S.; Overgaard, J.; Alsner, J.; Stemke-Hale, K.; Lluch, A.; Neve, R.M.; et al. Integrative analysis of cyclin protein levels identifies cyclin b1 as a classifier and predictor of outcomes in breast cancer. Clin. Cancer Res. 2009, 15, 3654-3662. [CrossRef] [PubMed]

(C) 2020 by the authors. Licensee MDPI, Basel, Switzerland. This article is an open access article distributed under the terms and conditions of the Creative Commons Attribution (CC BY) license (http://creativecommons.org/licenses/by/4.0/). 